\title{
Nina Ergin \\ Rock Faces, Opium and Wine: Speculations on the Original Viewing Context of Persianate Manuscripts
}

\begin{abstract}
One of the most delightful and interesting features of Islamic miniature painting in the Persian-speaking world is the appearance of hidden faces and figures in the background of compositions, which usually consist of rocky outcrops, tree roots or boulders. Scholars have provided different reasons for this feature, from narrative enhancement to the artists' creativity and imagination. Although accepting these reasons as valid, this paper proposes an additional raison d'être that is, the original viewing context of the majlis where wine and opium consumption were part of the entertainment, as both textual and visual evidence demonstrates. Based on first-hand accounts of users of psychoactive substances as well as psychological studies on their effect on creativity and visual perception, I argue that opium and wine consumption caused a perceptional shift that rendered the hidden figures even more entertaining than they would have been in a sober state of mind.
\end{abstract}

Keywords: Persian miniatures, rock faces, Ṣafavids, drugs

Nina Ergin: Koç University, Nergin@ku.edu.tr

\section{Introduction}

One of the most delightful and interesting features of Persianate miniature painting is the appearance of hidden faces and figures in the background of the composition, usually consisting of rocky outcrops, tree roots or boulders. The Shāhnā-

This article first started out as a seminar paper for the inspiring course "The Art of Iran", taught by Catherine Asher at the University of Minnesota, Minneapolis. A subsequent version was presented at the 2008 Annual Meeting of the Middle East Studies Association, on the panel "Arts of the Book in the Islamic World: Rethinking Categories." I wish to thank Emine Fetvacı and Persis Berlekamp, the organizers of this panel, for their fruitful comments and help with the relevant literature, as well as the audience for their many helpful questions. As Marianna Shreve Simpson told me on this occasion, Stuart Cary Welch had independently argued for the same point presented here; therefore, I wish to dedicate this article to his memory. For assistance with one of the images I thank Jan Mc Hugh and Tera Lee Hedrick. 
mah, painted in Tabriz in the first half of the sixteenth century for the Safavid ruler Shāh Țahmāsb (r. 1524-1576), is probably the most obvious example. In The Court of Gayūmarth, one cannot even begin to count the numerous minuscule faces and figures embedded in the colorful rocks (fol. 20v, fig. 1 and 1a). In The Feast of Sadah, entire figures holding animals and interacting with each other emerge from the rocks in the upper half of the image (fol. 22v, fig. 2 and 2a). In The Death of Zahhāk, rock faces seem to watch the events in the lower half of the composition; there is also a skull-like stone left of Zahhāk and a dragon in the swirling cloud bands in the upper left corner (fol. 37v, fig. 3 and 3a). The little faces in Zal is Sighted by a Caravan are strongly reminiscent of those in The Court of Gayūmarth, crowding the mountain in large numbers (fol. 63v, fig. 4 and 4a). ${ }^{1}$

There are also many earlier manuscripts with paintings that include rock faces, demonstrating that this phenomenon transcended the patronage of a specific period or dynasty and constituted a pictorial tradition that spanned at least the fourteenth through the sixteenth centuries. ${ }^{2}$ A Jalayirid example is a copy of Kalilah wa Dimnah, about 1360 and now in the Istanbul University Library (F. 1422). In The Lion-King Receives Shanzabah, crude mask-like faces protrude from behind and below the lion, and smaller worm-like creatures appear in the boulder above the ox (fol. 25v, fig. 5). Timurid painters also often incorporated hidden figures: in Farhād Carries Shīrīn from a 1439 copy of Niẓāmī's Khamsah, a delightful rock turtle crawls up the hill (Uppsala University Library, O. Vet. 82, fol. 78v, fig. 6). Another copy of Kalīlah wa Dimnah, made for Prince Bāyṣunghur (r. 1420-1433) in 1429 and now in the Topkapı Palace Library (R. 1022), includes at least eight full-page paintings with hidden faces. The small face on the outer edge of the lower left corner of The Elephants at a Pool is but one example of many (fol. 77r, fig. 7). ${ }^{3}$

A variety of reasons has been suggested for this playful handling of backgrounds and the popularity of hidden faces and figures in Persianate manuscript

1 Other paintings with hidden rock figures in this manuscript, although less prominent, include: Rustam Finds Kayqubād (fol. 110v), Rustam's Fourth Course: He Cleaves a Witch (fol. 120v), and The Story of Haftvād and the Worm (fol. 521v).

2 For a discussion of possible origins and precursors as well as a dynasty-by-dynasty historical development of this phenomenon see B. O'KanE, "Rock Faces and Rock Figures in Persian Painting," Studies in Persian Art and Architecture (Cairo: American University of Cairo Press, 1995), pp. 220-226.

3 For a more complete list of manuscripts with hidden faces and figures, see O'KANE, pp. 219-246. O'KANE is rather generous in identifying rock faces I would not see as such, since they might have emerged from an accidental setting of dots. Here, I have limited my examples to obviously intended ones. 
painting. In her discussion of the Kalilah wa Dimnah in the Istanbul University Library, Jill CowEN proposes that the faces and figures have a "narrative and dramatic function. [...] In reacting to the central animal characters, these spirits - the faces of nature - project the moods and actions of the animals and give voice to the supernatural." 4 Barbara BREND believes that "the answer [...] lies not with the subject matter, nor with the patrons, but with the artists." 5 Thomas LENTz echoes BREND's conclusion and sees their raison d'être in the artists' creativity and imagination: “A curious feature [...] is the appearance of 'rock spirits' or 'grotesques' among the outcropping of rock-caricatures that project more emotional and psychological insight than any of the human or animal figures in these illustrations, and which perhaps represent individual reactions to the severe restrictions governing this mode of painting." O'KANE also sees "the freedom of expression which rock faces afforded the painter" as the most likely reason. ${ }^{7}$ Such an interpretation surely is valid; however, one of the arguments upon which he rests this conclusion is a lack of connection between any specific type of text and the appearance of rock faces. ${ }^{8}$ Yet, when taking a closer look at his list of examples, there emerges a specific grouping: copies of the Shāhnāmah, Nizāmī's Khamsah, Kalilah wa Dimnah, anthologies and album pages. All of these texts, although also conveying political ideas and mystical concepts, could have been read for their pure entertainment value, at poetry gatherings and drinking parties (majlis). Thus, I propose an additional raison d'être - that is, the original viewing context of these specific manuscripts, which promoted an interactive reading of manuscripts. The emphasis here is not on the artist, but the complex interaction between viewer and artist, perception and intention, text and context. This context, convivial entertainment, would have included the ingestion of intoxicants in the form of wine, liquor, wine spiked with raw opium, and ma jūn (a slightly narcotic confection with delirious effects, made from raw opium, sugar, and aromatic spices, such as cinnamon, mace, cardamom, nutmeg, saffron and ambergris). These drugs would have affected a shift in perception, a shift that made the hidden faces and figures a most significant pictorial feature, even more entertaining than in a sober state of mind.

4 J. Cowen, Kalila wa Dimna: An Animal Allegory of the Mongol Court (New York, Oxford: Oxford University Press, 1989), p. 26.

5 B. BREND, "Rocks in Persian Miniature Painting," Landscape Style in Asia, ed. W. WATSon (London: SOAS, 1979), p. 120.

6 TH.W. LENTZ, Painting at Herat under Baysunghur ibn Shahrukh (PhD diss., Harvard University, 1985), pp. 99-100.

7 O’Kane, p. 227.

8 O'Kane, p. 226. 
The first section of this essay will briefly outline the theoretical framework of this study. Then, I will present both textual and visual evidence on the consumption of wine and opium in the courts of the early modern Persianate world, in particular in the context of the majlis setting. This will be followed by a consideration of how opium and psychedelic drugs may change visual perception based on firsthand accounts of users as well as experimental studies conducted by psychologists. Returning to an art historical discussion, the comparison between two psychedelic paintings and two masterpieces of Persianate painting indicates some remarkable parallels. The concluding remarks suggest wider implications for the study of Islamic manuscripts, in particular for the category of inquiry that can be termed the "original viewing context."

\section{Sensory Scholarship and the Intoxicated Period Eye}

Today, viewers of Persianate miniature paintings usually either contemplate the dismembered pages behind glass in a museum, displayed in the manner of a Western oil-painting, or they look at their reproductions in a book, embedded in a "scientific" text on Islamic art, with the aim to acquire a greater understanding of Persianate visual culture and history. Few viewers are privileged enough to be able to take a manuscript into their hands and leaf through it page by page; fewer still are those who can listen to the recited text while studying the miniatures up close. In contrast, the original viewing context might have been more similar to the intense experience of a visit to the Van Gogh Museum in Amsterdam after consuming marihuana in one of the city's koffieshops.

Intense viewing pleasure and the sensual experience of art have been banned from art historical study since Hegel's call for a scientific inquiry that discounts such experience and privileges mind over body. However, the sensorial turn in the social sciences, spearheaded by David Howes and Constance CLASSEN's work in sensory anthropology, ${ }^{9}$ has over the last decade or so begun to find wide reception in history as well as art history. ${ }^{10}$ Whereas sensory anthropology primarily

9 See D. Howes (ed.), The Varieties of Sensory Experience: A Sourcebook in the Anthropology of the Senses (Toronto: University of Toronto Press, 1991); C. Classen, Worlds of Sense: Exploring the Senses in History and Across Cultures (London, New York: Routledge, 1993); D. HowEs, Sensual Relations: Engaging the Senses in Culture and Social Theory (Ann Arbor: The University of Michigan Press, 2003); D. Howes (ed.), Empire of the Senses: The Sensual Culture Reader (Oxford, New York: Berg Publishers, 2005).

10 A synoptic overview over the field of sensory history up to 2007 can be found in M.M. SMITH, Sensory History (Oxford, New York: Berg Publishers, 2007). The 2010 annual meeting of the Col- 
aims to understand how sensory experience "varies from one culture to the next in accordance with the meaning and emphasis attached to each of the modalities of perception,"11 sensory history asks how people in the past saw, heard, smelled, touched and tasted, and how their experiences then translated into their cultural production - be that a literary text, an official document, or a work of art. Both anthropologists and historians are careful to locate the meaning and function of the senses in the specific historical and cultural context, arguing that sensory perception is never "natural" but always conditioned. Art and architectural historians have of course always dealt with vision in one way or another, and where sculpture is concerned also with touch, but over the last few years all of the senses have started to receive increased attention in studies questioning assumptions about how art is conceived of, how it is perceived, and how it might be studied.

Although the sensory approach so far has found only limited application in Islamic art history, ${ }^{12}$ an example from another field is Bissera PENTCHEVA's work on the sensory aspects of Byzantine icons, in particular ones in mixed-media relief such as the Treviso icon of the Mother of God which used to appear in the viewing context of a church's darkness, interspersed by flickering candles that produced shadows moving over its glittering gold surfaces. ${ }^{13}$ PENTCHEvA focuses on the aesthesis, or corporeal perception, of this devotional artwork, basing her

lege Art Association included two panels on sound: Art and Sound in the Premodern Era, and The Senses in Early Modern Art and Visual Culture. At the 2010 annual meeting of the Society of Architectural Historians, there was presented a panel entitled Sensational Space: Architecture and the 7 Senses and a plenary talk entitled $A$ Sense of the Past.

11 D. Howes, "Introduction: 'To Summon All the Senses', The Varieties of Sensory Experience, p. 3.

12 See N. ERgin, "The Soundscape of Sixteenth-Century Istanbul Mosques: Architecture and Qur'an Recital,” Journal of the Society of Architectural Historians 67 (2008), pp. 204-221; “A MultiSensorial Message of the Divine and the Personal: Qur'anic Inscriptions and Recitation in Sixteenth-Century Ottoman Mosques," Calligraphy in Islamic Architecture: Space, Form, and Function, ed. M. GHARIPOURI and I.C. ScHICK (Edinburgh: Edinburgh University Press, forthcoming 2013); "The Fragrance of the Divine: A Group of Ottoman Incense Burners in the Museum of Turkish and Islamic Art, Istanbul, and Their Context," The Art Bulletin 96/1 (forthcoming 2014); "Ottoman Royal Women's Spaces: The Acoustic Dimension," Journal of Women's History 26 (forthcoming 2014). For a more theoretical approach, see V. GonzalEz, "The Comares Hall in the Alhambra and James Turrell's The Space That Sees: A Comparison of Aesthetic Phenomenology,” Muqarnas 20 (2003), pp. 253-278.

13 B.V. Pentcheva, "Moving Eyes: Surface and Shadow in the Byzantine Mixed-Media Relief Icon," Res: Journal of Anthropology and Aesthetics 55/56 (2009), pp. 222-234. See also B.V. PenTCHEVA, “The Performative Icon,” The Art Bulletin 88 (2006), pp. 631-655; The Sensual Icon: Space, Ritual and the Senses in Byzantium (University Park: The Pennsylvania State University Press, 2010) and "Hagia Sophia and Multisensory Aesthetics,"Gesta 50 (2011), pp. 93-111. 
arguments on the object itself as much as on medieval textual sources. According to HowEs, "one of the aims of the sensual revolution is to recover perception from the laboratory"; 14 in the context of PENTCHEVA's and the present study, one may speak of "recovering perception from the museum."

A further concept that greatly helps in framing an inquiry into the sensory perception and original viewing context of Persianate miniature painting is Michael BAXANDALL's "period eye." ${ }^{15}$ BAXANDALL conceived of this concept to explicate how the cognitive apparatus of contemporary viewers of Italian Renaissance paintings was conditioned by their intellectual, social and physical environment - such as religious education, sermons, theater, dance and even the mathematical skills of the potential viewers. By embedding the making and viewing of paintings in a broader range of social practices outside the world of art, he argued for investigating art through the experiences of the contemporary viewer and, more generally, for an anthropology of visual culture. ${ }^{16}$ Given the state of knowledge about the historical context of the region and period and the nature of the sources, a comprehensive overview over the physical, social and intellectual realities of the original conditions of viewing Persianate miniature painting may never be attainable, even though much headway has been made. ${ }^{17}$ In any case, such an endeavor lies outside the scope of this study. Rather, I focus on only one intersection between visual traditions, sensory perception, and Persianate court culture between the fourteenth and sixteenth century: the consumption of mindaltering drugs at gatherings and parties that also included manuscript viewing in other words, the intoxicated period eye.

14 Howes, “Introduction: 'To Summon All the Senses'," The Varieties of Sensory Experience, p. 4. 15 M. BaXANDAlL, Painting and Experience in Fifteenth-Century Italy (Oxford, New York: Oxford University Press, 1974), particularly pp. 29-108.

16 For an overview over art historical and anthropological responses to BAXANDALL's work, see A. LANGDALE, “Aspects of the Critical Reception and Intellectual History of Baxandall's Concept of the Period Eye," Art History 21 (1998), pp. 479-497. The notion of the period eye, though intended to explain European pictorial traditions, seems well-suited to the study of Islamic art and architecture, although I am not aware of any publication in the field that explicitly draws on it. The change in the subtitle of Muqarnas - the foremost US-American journal devoted to Islamic art - from An Annual on Islamic Art and Architecture to An Annual on the Visual Culture of the Islamic World in 1996 - "visual culture" being a term that derives from Baxandall's work - shows that his contribution has permeated much of art history today, regardless of its regional context. 17 For an overview of the scholarship see D. Roxburgh, "The Study of Painting and the Arts of the Book," Muqarnas 17 (2000), pp. 1-16; see particularly pp. 3-4 for the line of inquiry into links between visual and wider culture. 


\section{Intoxicants in Persianate Court Culture}

There is abundant historical evidence for the consumption of both alcoholic beverages and opium in the Persian-speaking world, particularly at the princely and royal courts. Although the Qur'an prohibited the consumption of alcohol, ${ }^{18}$ wine was too significant an element in pre-Islamic Iranian culture to be given up easily. Campaigning and feasting (razm $u$ bazm) had belonged together since Sassanian times and as a theme occurred not only in Firdausi's Shāhnāmah, but also in later annalistic literature. ${ }^{19}$ Moreover, the Mongols brought with them from Central Asia a hard-drinking life style, as did the Georgians who as ghulām slave-soldiers made up a large part of the Safavid military forces. ${ }^{20}$ Wine-drinking was a matter of court etiquette and an integral part of kingship, and Lentz argues that among the Timurid royalty wine consumption seems "to have been encouraged and expected as a function of princely behavior." ${ }^{21}$ Even though many rulers seem to have wavered between guilty pleasure and abstention, all but the most orthodoxminded rulers imbibed. ${ }^{22}$

Wine was drunk almost exclusively by the elite, by courtiers, and occasionally also by Sufis with the expressed aim to achieve intoxication and, especially in the case of the latter, ecstasy. Often, wine would be spiked with additives - such as chalk, hempseed or raw opium - to enhance its kick (damāgh). ${ }^{23}$ Opium, which in contrast to alcohol did not have a religious stigma attached to it, was consumed more widely and in many different forms. Opium was not only added in its raw form to wine, but also swallowed as pills, taken as barsh (a compound drug with hallucinogenic qualities), drunk as kūknār (water in which bruised poppy capsules had been soaked), and eaten in the form of different types of confections (ma'jūn, filūniyah, possibly also kamali). ${ }^{24}$ Smoking opium in a pipe was only in-

18 See suras 2:219, 4:43, 4:46, 5:90-91, 16:66.

19 R. MATtheE, The Pursuit of Pleasure: Drugs and Stimulants in Iranian History, 1500-1900 (Princeton: Princeton University Press, 2005), p. 49.

20 MattheE, pp. 41-43.

21 LENTZ, Painting at Herat under Baysunghur ibn Shahrukh, p. 48.

22 A good example here is Shāh Tahmāsb who gave up drinking later in life and banned alcohol and other drugs with his Edict of Repentance. For a narrative of Safavid rulers and their relationship to alcohol, see MATTHEE, pp. 49-57.

23 MatTheE, p. 44.

24 MattheE, pp. 102 (barsh), 105 (kūknār), 111 (filūniya). Kamali is mentioned in The Baburnama: Memoirs of Babur, Prince and Emperor, transl., ed., and annotated by W.M. THACKsToN (New York: The Modern Library, 2002), p. 267. I have not been able to find this term in any dictionary, and Thackston does not include diacritical marks. Although the ingredients of this confection are not known with any certainty, Babur's description of its effects makes it likely to contain opium. 
troduced to the Persianate world much later, and the effects of smoking the drug apparently differ much from ingesting it. ${ }^{25}$

The physician Avicenna (b. 980, Bukhara), himself an addict, mentioned the drug favorably in his Canon of Medicine as a panacea against all sorts of diseases. Apart from medicinal uses, it also served spiritual and recreational purposes. Travelers compared the way in which Iranians ate opium to the manner in which the French drank wine, without necessarily becoming addicted to it. ${ }^{26}$ As with wine, the consumption of opium had been a part of court culture and entertainment since Sassanian times. Firdausi wrote about its role at court in the following way: "In the time of war he who uses opium is poison/ in the time of feasting, a world-enlightening moon.”27 Several centuries later, Hāfiz (ca. 1326-1390) also referred to the consumption of opium at courtly gatherings: "Because of the opium which the cup-bearer cast in the wine/ there shall remain to the company neither head nor turban." 28

\section{The Majlis Setting}

The feasting to which these two poets refer took place in the form of a majlis. $M a$ jālis were held on a wide variety of occasions: births, circumcisions, marriages, successful campaigns, the reception of diplomatic envoys, religious holidays, scholarly debates on legal and religious subjects (majlis al-munāzara), literary meetings, and for recreation. Based on where the guests met, the format could be rather formal and with a fixed hierarchical seating order if held at a ruler's court or in a dignitary's house (majlis-i 'ālì), or more informal, with merry drinking and eating (șuhbat). ${ }^{29}$ In either case, guests would recite and critique poetry and other literary works, relate anecdotes, listen to music, watch and maybe also join dancers, flirt with the cup bearers, and ponder and discuss beautiful images and scenery if the location allowed. Depending on the function of the gathering, the host would invite his boon companions (nudamā', sing. nadìm), high military officers, dignitaries, courtiers, scholars, poets and artists. The location of a majlis

25 Matthee, pp. 210-213.

26 Matthee, p. 12.

27 Quoted after A.R. Neligan, The Opium Question, With Special Reference to Persia (London: John Bale Sons \& Danielsson, 1927), p. 8.

28 Quoted after NELigan, p. 9.

29 For the terminology of these types of gatherings see D. BrooKshaw, "Palaces, Pavilions and Pleasure-Gardens: The Context and Setting of the Medieval Majlis," Middle Eastern Literatures 6 (2003), p. 199. 
could range from an audience hall or assembly room inside the palace to gardens, pavilions, tents, and even scenic spots in untamed nature. ${ }^{30}$

The Zafarnāmah, compiled by Sharaf al-Dīn 'Alī Yazdī around 1425 for Ibrāhīm Sulțān (r. 1415-1435), the son of Shāhrukh (r. 1406-1447), describes an outdoors gala jamboree just outside of Samarkand in 1404, including all the victuals offered to the guests:

From end to end were goblets of jade and crystal filled with wine, koumiss, honey, muthallath [thrice distilled liquor], liquor and sherbet. (...) When the princes and noyans [high military officers], in accordance with the custom and ritual, drained one after another their goblets filled with ruby-red wine, and the ritual of toasting ( qos u qarav) were completed, trays laden with more food and multitudes of more various edibles were set than can be described. Of that feast one can say without exaggeration, therein shall they enjoy whatever their souls shall desire, and whatever their eyes shall delight in (...). ${ }^{31}$

It is not inconceivable that on this occasion some souls desired for their wine to be spiked with opium, or that their eyes delighted in ma'jūn.

Particularly plentiful in references to the consumption of alcoholic beverages and opium in the Persianate world of the late fifteenth and early sixteenth centuries is the Bāburnāmah. As a Timurid prince, Bābur shared in the Turco-Mongol customs and traditions which included drinking parties as a form of leisure and male bonding, and his memoirs contain innumerable references to both intoxicants and several longer descriptions of drinking parties. ${ }^{32}$ In Bābur's world, the beholding of beautiful scenery was so much associated with drinking that a tour of the autumn harvest could lead to an impromptu outdoor majlis:

30 On the various types of majālis, their setting and the activities associated taking place, see D. Roxburgh, Prefacing the Image: The Writing of Art History in Sixteenth-Century Iran (Leiden: Brill, 2001), p. 65; E.M. SubTelny, “Art and Politics in Early Sixteenth Century Central Asia," Central Asiatic Journal 27 (1983), pp. 139-140; and in particular BRooKsHAw.

31 W.M. Thackston (ed. and transl.), A Century of Princes: Sources on Timurid History and Art (Cambridge: Agha Khan Foundation, 1989), p. 97.

32 In the Bāburnāmah, I counted 61 passages referring to alcoholic beverages (mostly wine, but also beer, spirits and date wine). See Thackston, Baburnama, pp. 17, 22, 23, 25, 28, 31, 51, 60, 82, 101, 114, 153, 154, 159, 160, 181, 194, 197, 199, 205, 207, 209, 215, 224, 226-229 (extensive description of a drinking party), 268, 275, 276, 277, 278, 283, 285, 286, 287, 288, 291, 293, 294, 295, 297, 298, 299 , 300, 301, 302, 303, 304, 305, 310, 311, 313, 314, 319, 327, 347, 369, 373, 376, 379, 380, 381-383, 436. On 31 pages, Bābur refers to opium (mostly in the form of $m a$ ' $j u ̄ n$, but also as pure opium for medical purposes and kamali). See ThAскsтon, Baburnama, pp. 10, 267 (kamali), 275, 276, 277, 281, 290, 291, 295, 299, 300, 302, 303, 304, 309, 310, 311, 314, 322, 397, 403, 413, 417, 425, 430, 437, 438, 442, 443, 448, 455, 457. 
At midday, we rode out to Istalif, having some ma'jun [sic] along the way. In the late afternoon, we came to Bihzadi. The autumn was beautiful. While touring the harvest my companions who were inclined to wine began to agitate for some. [...] since the autumn colors were so beautiful, we sat down under the colorful trees and drank. The party continued there until late that night. ${ }^{33}$

Of particular interest in the context of this study is Muẓaffar Mīrzā's party in 912 (1516/1517), since it took place in a setting that included paintings, as Bābur describes:

After dinner was served [...], Muzaffar Mirza took us to an edifice built by Babur Mirza called the Tarabkhana [joy-house], where a drinking party was held. The Tarabkhana was situated in the middle of a small garden. It was a modest building of two stories and rather pleasant. The upper level had been elaborately constructed. Each of the four corners had an alcove, but otherwise the space in the middle and between the alcoves was like one room. Between the alcoves were things like shahnishins [platforms with raised sides]. Every side of the room was painted; the work had been commissioned by Sultan-Abusa'id Mirza to depict his battles and encounters. [...] The pleasure cups were filled and the cupbearers began to circulate and offer them to the guests, who started gulping down the clear wine as though it was the water of life. The party grew heated as the wine went to people's heads. ${ }^{34}$

The fact that Bābur mentions the paintings and their contents as well as the name of their patron demonstrates that the paintings were more than just an incidental component of the setting; in all likelihood, the party guests admired and discussed the images in detail before they became too intoxicated. This is not a singular instance of a majlis being held in a building with wall paintings; many other examples have been discussed elsewhere. ${ }^{35}$ From the beholding of wall paintings it is but a small step to the beholding of paintings on paper. Indeed, Wāṣifi mentions an anecdote in which Bihzād at a gathering presented to Mīr 'Alī Shīr Nawā'ī a portrait of the recipient in a garden. This painting was then passed around and discussed by the guests. ${ }^{36}$

Not only textual primary sources give evidence of the consumption of intoxicants, but also a number of paintings. Of the many portraits of patrons or rulers holding a precious wine cup, that of Prince Bāyṣunghur seated in a garden, on the frontispiece of his 1429 Kalīlah wa Dimnah (fol. 1b, fig. 8), has particular relevancy

33 ThaCKSTON, Baburnama, p. 299.

34 Thackston, Baburnama, p. 226.

35 BRoоKshaw, pp. 207, 219, n. 146, n. 155.

36 Zayn al-Dīn Wāṣifí, Badāi’’ al-Wakāi', ed. A.N. Boldyrev (Moscow: Izdat. Vost. Lit., 1961), pp. 907-910. This passage is also discussed in Subtelny, p. 144, and RoXBuRgh, Prefacing the Image, p. 70. 
here. Bāyșunghur was not only a pleasure-loving aesthete and great patron of manuscripts, but also an alcoholic (which suggests that he consumed opium as well), and the paintings which this frontispiece prefaces include many rock faces (see fig. 7). A more informal drinking party is the subject of Bihzād's frontispiece to the Būstān of Sa'dī from 1488/1489, made for Sultān Husayn Mīrzā and now in the National Library in Cairo (fols. 1v and 2r, fig. 9a and 9b). Entitled A Royal Feast and painted with a keen gift for the observation of human folly, the double-page composition depicts a party at the patron's court. Several participants are clearly intoxicated, as they need help walking or have passed out. Still, the wine keeps flowing, and servants are busy refilling flasks. In the lower right corner of the exterior scene, a dark-skinned servant carries a basket full of goodies on his head - maybe these goodies also include some ma jūn (fig. 9b). In the lower right of the other page, a seated guest holds a book in his hand, demonstrating that manuscripts indeed were perused on such occasions (fig. 9a). Probably the most pointed visual example of wine and books being consumed together is a detail in Sulțān Muhammad's Ode to Drunkenness in a copy of Hāfiz’s Dīvān from 1527, now in the Arthur M. Sackler Gallery (fol. 135, fig. 10). In an upper-story room, the poet Hāfiz himself lounges on a cushion, with a manuscript in his lap and a wine flask and cup at his feet (fig. 10a). ${ }^{37}$ His facial expression speaks of intense concentration on the contents of the page, although it is unclear whether these consist of a poem or a painting.

\section{The Effects of Opium on Visual Perception}

Having established that the consumption of opium was indeed an integral part of Persianate culture and court life, a further question poses itself: What effects does opium have on the period eye? Unfortunately, I have not been able to uncover any sources contemporary to the manuscripts discussed here, sources that mention how a Jalayirid, Timurid or Safavid prince experienced a high in terms of visual perception. Therefore, I will resort to more recent descriptions of experiences under the influence of drugs, although I am well aware of the dangers of crosscultural and retrogressive comparisons. ${ }^{38}$ In the light of recent research into the phenomenology of drug use, a given intoxicant in fact often does provoke similar

37 I am indebted to Marianna Shreve Simpson for pointing out that this figure is the poet Hāfiz himself.

38 I have not attempted to re-create such an experience by way of self-experiment, for two reasons: First, I was not able to find a recipe for the preparation of $m a$ ' jūn. Secondly, an art historian who lives in a world inundated with images might react much less to visual stimuli than a Persian of the medieval or early modern period would have. 
psychological responses across cultures and time-periods, including strikingly similar hallucinogenic images..$^{39}$ For example, a claim that many opium users make is that it heightens mental powers and activities and that it makes "intellectual faculties [...] ready, vivacious, lucid, and ideas [...] copious and original." 40 Opium makes all senses intensely acute, to the point where sound and visual stimuli can become painful. ${ }^{41}$

Thomas DE QUINCEY (1785-1859), author of Confessions of an English Opium Eater, used to take the drug before visiting the opera, so that he could take in the performance with heightened senses: "Now opium, by greatly increasing the activity of the mind generally, increases, of necessity, that particular mode of its activity by which we are able to construct out of the raw material of organic sound an elaborate intellectual pleasure." $42 \mathrm{He}$ also mentions that it powerfully affects the sense of space and time. ${ }^{43}$

Examples of visual rather than aural perception as altered by opium abound in the literature. Theophile Gautier (1811-1872) describes his experience as follows: "Around me streamed and rolled precious stones of all colors. In space, flower patterns branched off ceaselessly in such a way that I can only compare them to the play of a kaleidoscope." ${ }^{44}$ It would certainly go too far to attribute to the consumption of opium the arabesque patterns on the manuscripts' carpet pages or on the walls of the architecture depicted; however, the sensual impact of the patterns on the intoxicated viewer must have been stunning.

Martin Воотн seems to draw on his own experience when he describes the effects of opium on the perception of color: "In an opium dream, reds darken to maroons and blood crimsons, blues blacken to the color of an early night sky, whilst yellows become solid and more luminescent. What is more, colors take on an almost tangible texture, so the hue becomes only a part of their impact: one does not just see them, one also feels them." ${ }^{45}$ This description should be kept in mind particularly when examining the splendid colors used, for instance, in The Court of Gayūmarth. Did the inebriated courtiers undergo similar synaesthetic experi-

39 See B. Shanon, The Antipodes of the Mind: Charting the Phenomenology of the Ayahuasca Experience (Oxford: Oxford University Press, 2003).

40 A. HAYter, "Opium and the Romantic Imagination: Addiction and Creativity," in: De Quincey, Coleridge, Baudelaire and Others (Wellingborough: Crucible, 1988), p. 43.

41 HAYTER, p. 54.

42 TH. DE Quincey, Confessions of an English Opium Eater (London, New York: Penguin, 1986), p. 79.

43 DE QUINCEY, p. 103.

44 As quoted in N. Gosling, "Snakes in the Grass," Art \& Artists 4 (1969), p. 26.

45 M. Воотн, Opium: A History (New York: St. Martin’s Griffin, 1998), p. 38. 
ences at the sight of the painting's fanciful hues? Certainly, a refined majlis would have offered a feast that addressed all five senses - in addition to the beautiful paintings, natural scenery and lovely attendants for the eye, there were wine and aromatic nibbles for the palate; poetry and music for the ear; the scent of flowers and perfume for the nose; and luxurious fabrics and precious cups for the hands to touch. Thus, the setting would have been conducive to a convergence of the different modalities of perception.

Altered visual perception can also mean the addition of movement to an inanimate image, as suggested in this description of the beholding of Henri Rousseau's Sleeping Gypsy (1897, fig. 11) while under the influence of LSD: "Studying the bulge-eyed beast in that painting, I saw its mane is all dendrites and energy pulses through each branch and is transmitted to the brain of the sleeping gypsy. The beast seemed to be sniffing, while the moon shimmered and winked and smiled, and the strings of the instruments that lay upon the ground were plucked by an invisible hand." 46 The implications of this passage for the intoxicated period eye looking at a Persianate manuscript are quite obvious: not just the hidden faces, but all figures and beasts must have come to life, breathing and moving and cavorting.

A further description of the features of drug-induced illusion can be applied to Timurid and Safavid painting almost wholesale: these features are "intense awareness of unrelated scraps of vision, result[ing] in abnormal clarity and brilliance of detail or colour - something demonstrated by many painters and poets [...] and summarized [...] as seeing 'infinity in a grain of sand."' 47 This does not necessarily mean that all painters knew the effects of opium on visual perception and fashioned their images accordingly. However, their detailed and brilliantly clear and colorful style complimented the heightened sensory perception under the influence of intoxicants.

Another argument for painters purposefully including figures in order to enhance viewing while under the influence derives from experiments conducted by psychologists to study the influence of psychedelic drugs on creativity and problem-solving. In one particular study, subjects were asked to complete specific tasks before and after taking LSD, mescaline or other mind-altering drugs. ${ }^{48}$ One

46 R.E.L. MASTERS \& J. Houston, The Varieties of Psychedelic Experience (New York: Holt, Rinehart and Winston, 1966), p. 10.

47 Gosling, p. 28.

48 W. Harman, R. McKim, R. Mogar, J. Fadiman \& M. Stolaroff, "Psychedelic Agents in Creative Problem-Solving: A Pilot Study,” Psychological Reports 19 (1966), pp. 211-227. For an overview over this and similar studies see S. KRIPPNER, "Psychedelic Drugs and Creativity," Journal of Psychoactive Drugs 17 (1985), pp. 235-245. More recent publications on the influence of mind-al- 
of these tasks consisted of the Witkin Embedded Figures Test, which involves having to recognize a simple geometric figure within a larger and more complex colored figure - a task very similar to distinguishing the hidden faces and figures in black line drawing among the colorful rocks in Persianate miniatures. Compared to their performance in a sober state, all but one subject improved on this task as much as 200 percent and were able to find figures with much greater speed. This suggests that the shift in visual perception while under the influence is "in the direction of enhanced ability to recognize patterns, to isolate and minimize visual distraction, and to maintain visual memory in spite of confusing color and spatial forms." 49 If drugs can indeed heighten the capacity for recognizing embedded figures to such an extent, and if this was known to Persianate miniature painters, they certainly would have taken advantage of this knowledge, not least to please the patrons.

One also has to acknowledge the possibility that the painters themselves took opium. The consumption of drugs with the aim to enhance creativity has a long history that predates the making of the manuscripts under discussion. The archaeologist Peter STAHL has argued for the Neolithic sculpture of the Tisza culture of present-day Hungary, as well as for the ceramics produced by the Ecuadorian Valdivia, that their designs and motifs are "representations of images perceived during ritually altered contact with hidden worlds under the stimulation of hallucinogenic substances."50 The Romantic painter Dante Gabriel Rossetti (1828-1882) and the Art Nouveau graphic artist Aubrey Beardsley (1872-1898) consumed opium. ${ }^{51}$ As for Persian painters, we do know that Bihzād was a heavy drinker who "could not live for a moment without ruby-red wine or the ruby-red lips of a wine-bearer" and who in spite of an imperial ban on alcohol continued to drink with the knowledge of the shah. ${ }^{52}$ Bihzād was only one of the many artists

tering drugs on creativity include: L. RAUCH, "The Poet Syndrome: Opiates, Psychosis and Creativity,” Journal of Psychoactive Drugs 32 (2000), pp. 343-349; J. TEN BERGE, "Jekyll and Hyde Revisited: Paradoxes in the Appreciation of Drug Experiences and Their Effects on Creativity,” Journal of Psychoactive Drugs 34 (2002), pp. 249-262; and M.T. JonEs, "The Creativity of Crumb: Research on the Effects of Psychedelic Drugs on the Comic Art of Robert Crumb," Journal of Psychoactive Drugs 39 (2007), pp. 28-291.

49 HaRman et al., p. 219.

50 P. Stahl, "The Hallucinogenic Basis of Early Valdivia Phase Ceramic Bowl Iconography," Journal of Psychoactive Drugs 17 (1985), p. 113; P. STAHL, "Identification of Hallucinatory Themes in the Late Neolithic Art of Hungary,” Journal of Psychoactive Drugs 21 (1989), pp. 101-112.

51 GosLing, p. 26.

52 Būdāq-i Munshī-yi Qazvīnī, Javāhir al-Akhbār, 1576, State Public Library, St. Petersburg, Dorn 288, fol. 111r. As quoted in: A. SoudAvar, "Between the Safavids and the Mughals: Art and Artists in Transition," Iran 37 (1999), p. 51. 
who circumvented Shāh Tahmāsb's repeated bans on alcohol, drugs and other worldly pleasures: they either chose to ignore the edicts, or left for the Mughal Empire or the court of Sultān Ibrāhīm Mīrzā in the province of Khurasan. ${ }^{53}$

In a number of the above-mentioned studies and experiments, professional artists were among the test subjects given mind-altering drugs and then asked to paint and draw. Summarizing these studies, KRIPPNER concludes that the visions produced by hallucinogenic drugs can and do serve as inspiration for artists, writers and musicians, especially since visualization of the completed solution to a specific creative problem is one of the eleven factors that improve with the ingestion of mind-altering drugs. ${ }^{54}$ However, the motor skills necessary to communicate these ideas decrease, and although the resulting works often have great aesthetic merit, their technical execution suffers. Thus, Timurid, Turkmen and Safavid painters would not have been able to use their extremely fine brushes adequately in a state of intoxication. Yet, it is conceivable that artists devised their color schemes and detailed compositions teeming with hidden figures after having consumed ma jūn or wine spiked with opium.

\section{Hippies and Persian Princes}

While it may not prove whether the painters and viewers of Persianate miniatures indeed took drugs, a comparison between psychedelic art of the 1960s and Persianate manuscript illustrations shows some remarkable similarities. Psychedelic art is conceived and/or executed under the influence of psychedelic drugs (such as LSD, mescaline, or peyote) and reflects drug-induced visions. ${ }^{55}$ It also includes art created specifically for viewing while intoxicated. As a movement, psychedelic painting emerged in the mid-sixties and was intimately tied to the hippie culture of the San Francisco Bay area. Its imagery was widely circulated in the form of concert announcement posters or posters decorating the walls of socalled "head shops" where one could buy and consume drugs. Stylistic hallmarks include "vivid color, vibrant energy, flowing organic patterns, and a tendency to compress time and space so that images from the most disparate cultures and time periods were brought together in elaborate montages." 56

53 SOUdAVAR, p. 51.

54 KRIPPNER, p. 239.

55 D. SoкоL, "Psychedelic Art," The Grove Dictionary of Art, available from http://www. groveart.com.

56 Th. Albright, Art in the San Francisco Bay Area, 1945-1980: An Illustrated History (Berkeley, Los Angeles: University of California Press, 1985), p. 169. 
Gage Taylor's Mescaline Woods (1969, fig. 12) with its hyper-realistic rendition of every single branch, leaf and flower exhibits the heightened awareness of visual elements after the ingestion of mescaline. Exaggeratedly gnarled trees seem to writhe and cavort. The variety of plants in different shades of green, brown, yellow and red is enormous. Colorful flowers punctuate and accent the foliage and shrubbery which are spanned by an impossibly blue sky, dotted with tufts of clouds. Rustam Sleeping While Rakhsh Fights the Lion, a detached page from an early-sixteenth-century unfinished Shāhnāmah copy from Tabriz (British $\mathrm{Mu}$ seum, fig. 13) constitutes only one of many examples of similarly hyper-realistic attention to detail in the illustration of landscapes. Every single branch, leaf and flower is visible. Trees, bushes, and even rocks appear to breathe and move with the events of the narrative. Two vicious-looking faces are discernible in the blue rocky outcrop, one resembling a snarling lion. The green boulder also contains hidden faces, one of them looking down on the fight between the lion and the horse.

Irene McHugh's commercial poster with the title Pipe Dreams (ca. 1968, fig. 14) can serve as a useful comparandum for The Court of Gayūmarth (fig. 1). Both compositions feature an ovoid surrounded by colorful elements; stylized flowers on the poster and rocks in the miniature. In both images, vibrant colors are set against each other in strong contrast, and the figural elements are almost consumed by the background and become clearly visible only upon closer inspection. The hidden faces and figures in The Court of Gayümarth demand even more work from the viewer. Although Pipe Dreams as a whole can be contemplated merely as an abstract study of color, after a while one can discern specific figures: starting from the top and proceeding clockwise, there emerge a sunburst, a bearded face, a mushroom, a genie lamp, three rabbits arranged in an emblem, an egg, a peacock, the head of a fire-spewing dragon and an apocalyptic rider. The center is occupied by one figure falling down head-first and another standing upright. It is no far stretch of the imagination to say that a hippie under the influence of LSD would find a prolonged contemplation of this poster as joyful and pleasure-inducing as a Persian prince high on opium-spiked wine or ma jūn would find looking at The Court of Gayūmarth. ${ }^{57}$

57 Since Islamic painting traditions achieved more popular visibility in the US in the 1960s, it is not impossible for psychedelic artists to have seen some of the Persianate paintings discussed here and to have drawn inspiration from them. 


\section{Concluding Remarks}

Since the beginnings of scholarly inquiry into Islamic manuscript paintings in Europe and the US, many scholars have attempted to arrive at a categorization based on different criteria. A list of these categories ${ }^{58}$ - neither comprehensive, nor privileging any specific approach since all have their merits as well as shortcomings - may include: chronology or sequence; collection of works; ${ }^{59}$ dynasty; ${ }^{60}$ region or school of painters; ${ }^{61}$ codicology, including painting technique and materials; 62 individual artist; 63 style; 64 literary and pictorial genres; 65 iconography; 66 themes that can also lie outside the art work itself; 67 and, as considered here, the original viewing context. ${ }^{68}$ In reference to the latter, David RoXBURGH has com-

58 In compiling this list, I have profited from several works that give an overview over the field: O. Grabar, Mostly Miniatures: An Introduction to Persian Painting (Princeton: Princeton University Press, 2000); RoxBurgh, "The Study of Painting”; M.S. Simpson, "Islamic Painting and History," Asian Art 1 (1988), pp. 3-6. A classification somewhat difficult to apply can be found in L. Golombeк, "Toward a Classification of Islamic Painting," Islamic Art in the Metropolitan Museum, ed. R. EtTinghausen (New York: Metropolitan Museum of Art, 1972), pp. 23-34.

59 See, for example, Th.W. Lentz, "Pictures for the Islamic Book: Persian and Indian Painting in the Vever Collection,” Asian Art 1 (1988), pp. 9-35.

60 See, for example, the discussion of art under the Timurid dynasty in TH.W. LENTz \& G. Lowry, Timur and the Princely Vision: Persian Art and Culture in the Fifteenth Century (Los Angeles: Los Angeles County Museum, 1989).

61 According to Simpson, the regional approach has been introduced by B.W. Robinson. See Simpson, p. 3.

62 For an overview see Y. PORTER, Peinture des arts du livre: Essai sur la literature technique indopersane (Louvain: Peeters, 1992), and J. PedERSEN, The Arabic Book (Princeton: Princeton University Press, 1984).

63 See S. CAnBy, The Rebellious Reformer (London: I.B. Tauris, 1996) on Riza-i Abbasi, and E. BAHARI, Behzad: Master of Persian Painting (London: I.B. Tauris, 1996).

64 See, for example, O. Grabar, "Persian Miniatures: Illustrations or Paintings," The Persian Presence in the Islamic World, ed. R. Hovannisian and G. SABAGH (Cambridge: Cambridge University Press, 1998), pp. 199-217.

65 See R. Ettinghausen, “The Categorization of Persian Painting," Studies in Judaism and Islam, ed. S. MoRAG (Jerusalem: Magnes Press, 1981), pp. 55-63, for an approach matching literary with pictorial genres. For a discussion of albums as a separate genre, see RoXBURGH, Prefacing the Image.

66 See, for example, СH. Gruber, “The Prophet Muhammad's Ascension (Mi'raj) in Islamic Painting and Literature: Evidence from Cairo Collections," Bulletin of the American Research Center in Egypt 185 (2004), pp. 24-31.

67 The theme of legitimacy as it relates to all arts, including the arts of the book, has been discussed for the Timurid dynasty by LENTZ and LowRY.

68 Studies of the original viewing context have so far mostly been limited to relations between text and image. Shāhnāmah illustrations meant to accompany recitals are the subject of 
mented: "It is strange that after a century of studying the arts of the book and in the wake of social history, so little has been written about the social context of Perso-Islamicate books and about how and where readers used them. Patterns of exchange by gift, acquisition through inheritance and booty, and the social groups that had access to books are now attracting greater attention, but modalities of reading texts [...] have been largely ignored." 69

Here, I have limited my discussion of the original viewing context and modality of sensory perception to that of a majlis accompanied by the ingestion of intoxicants, but the category of original viewing context clearly can branch out into many sub-categories. Among others, these sub-categories may include, again in no particular order: preparatory manuscripts with rough sketches or low-quality illustrations, made as a guideline for artists to determine the layout of the final copy; luxury manuscripts, sometimes to be given as gifts; Qur'an copies for recitation, bound in sections to be read in one sitting; manuscripts for educational purposes, sometimes with stories written in easy-to-read letters and more accessible language, sometimes similar in purpose to a "world history textbook" for the training of royal pages; fālnāmah manuscripts used for fortune-telling by randomly opening the pages in search for the oracular answer to a specific question; and texts deemed appropriate as bedtime literature, often read aloud by a steward to the court member or ruler. ${ }^{70}$ While in some cases sources such as chronicles, literary texts or archival documents may allow manuscripts to be classified into these categories, at other times the manuscript's content and format may suggest such a categorization, as, for example, in the case of preparatory manuscripts or educational primers. Ideally, both exterior textual evidence and the evidence provided by the manuscript itself may prove the original viewing context beyond a doubt.

At this point, it cannot definitively be proven that the period eye really was an intoxicated one on occasion. We do not know with any certainty whether Persia-

B. MAHIR, “A Group of Paintings Used for Picture Recitation,” Turkish Art: Proceedings of the Tenth International Congress of Turkish Art (Geneva: Fondation Max van Berchem, 1999), pp. 443-456, and N. ATASoy, "Illustrations Prepared for Display During Shahname Recitals," Fifth International Congress of Iranian Art (Tehran: Ministry of Culture and Arts, 1972), pp. 262-272. For a study of early Shāhnāmah copies, see M.S. SimpSon, The Illustration of an Epic: The Earliest Shahnama Manuscripts (New York: Garland, 1979).

69 RoXBurgh, Prefacing the Image, p. 62.

70 Most of these categories have been derived from E. Fetvac1, Viziers to Eunuchs: Transitions in Ottoman Manuscript Patronage, 1566-1617 (PhD diss., Harvard University, 2005). On a preparatory manuscript, see p. 266; on educational books, see pp. 37 and 46; on a fālnāmah manuscript, see p. 319; on bedtime reading, see p. 34 . 
nate viewers of manuscripts did indeed take ma'jūn with the specific aim to enhance their experience, ${ }^{71}$ or whether painters were inspired by opium dreams, or whether they incorporated hidden rock faces and figures for viewing under the influence. However, it is equally impossible to disprove this hypothesis. More important than proving or disproving the use of opium for viewing pleasure is to strive towards a recovery of the original viewing context and sensory perception of manuscript paintings from the academic or museum context in which they are usually found today. Thus, their study should not be limited to categories of inquiry anchored in these contexts - be that a context of strictly "scientific" inquiry, or the manifestation of a "national spirit" in a state museum. The intense sensory experience of art under the influence of intoxicants might not be easily conceivable to today's viewer, but it could well represent one of a range of possible original viewing contexts.

71 It is possible that traces of opium remained on the manuscripts themselves if the viewers did not wash or wipe their hands between putting a piece of $m a$ 'jūn into their mouth and turning the pages. I am grateful to one audience member at MESA for pointing out this possibility. 


\section{Figures}

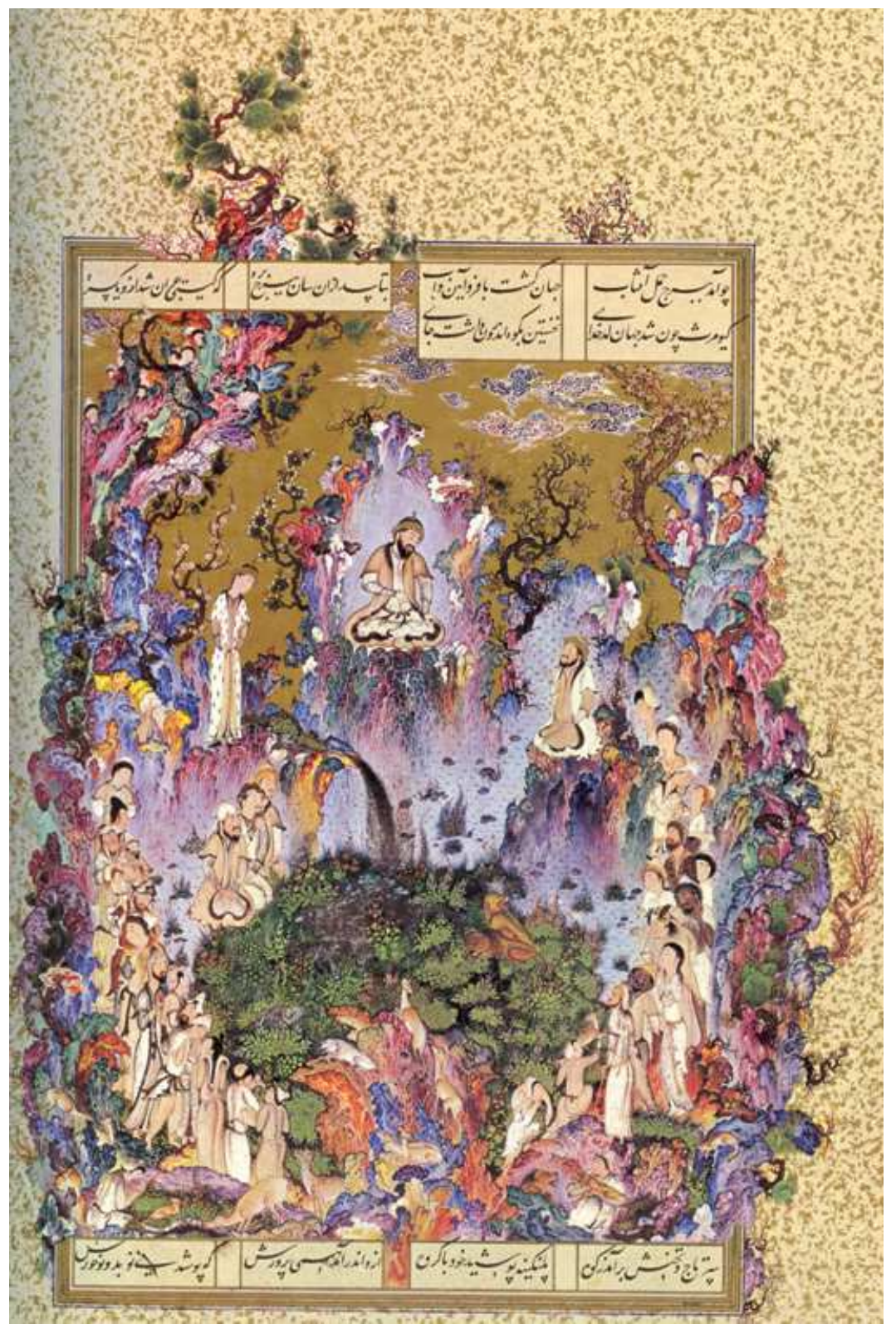

Fig. 1: The Court of Gayūmarth, Shāh Tahmāsb Shāhnāmah, first half of sixteenth century. Metropolitan Museum of Art, 1970.301.2, fol. 20v. 


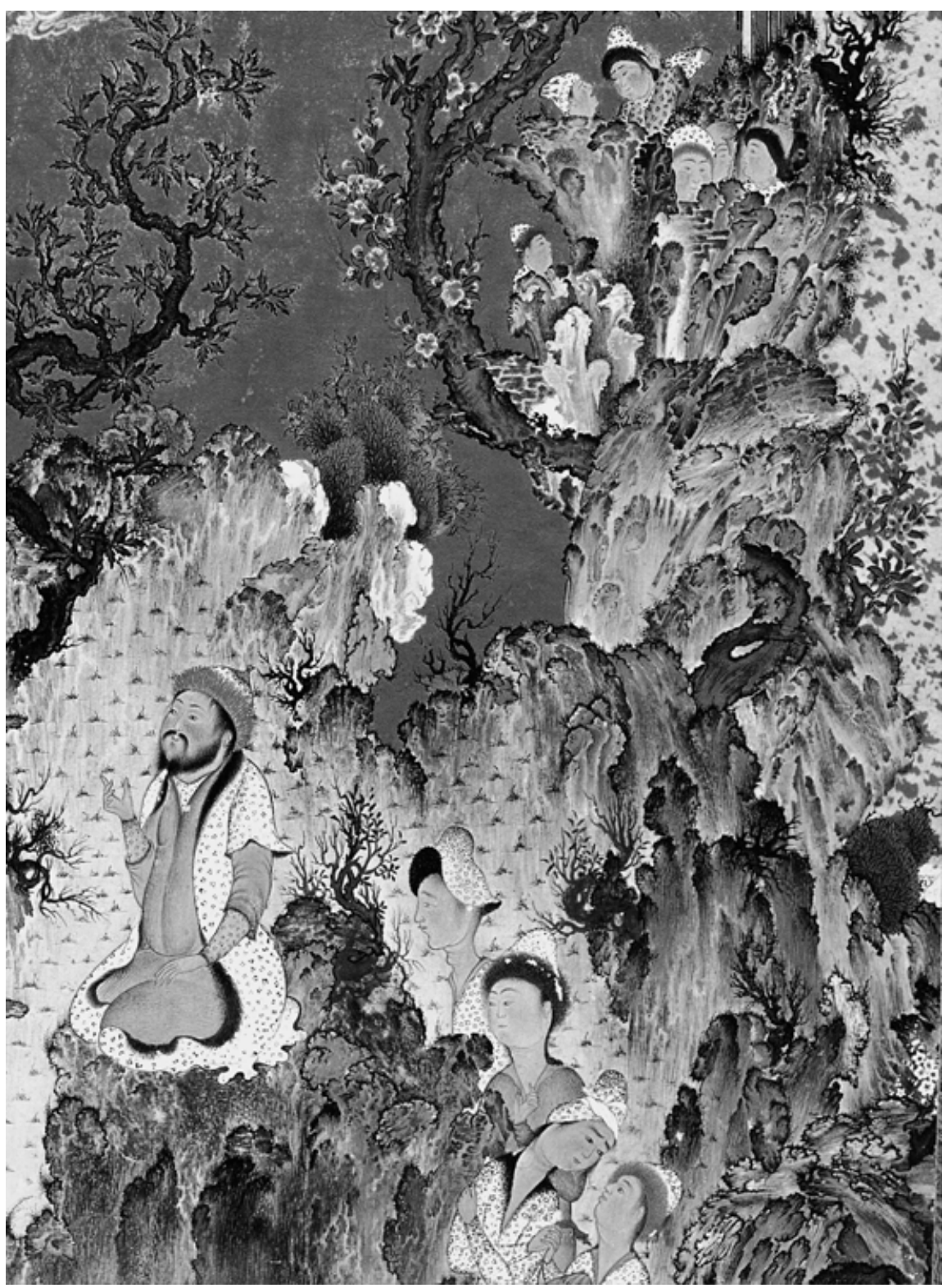

Fig. 1a: Detail of The Court of Gayūmarth, Shāh Tahmāsb Shāhnāmah, first half of sixteenth century. Metropolitan Museum of Art, 1970.301.2, fol. 20v. 


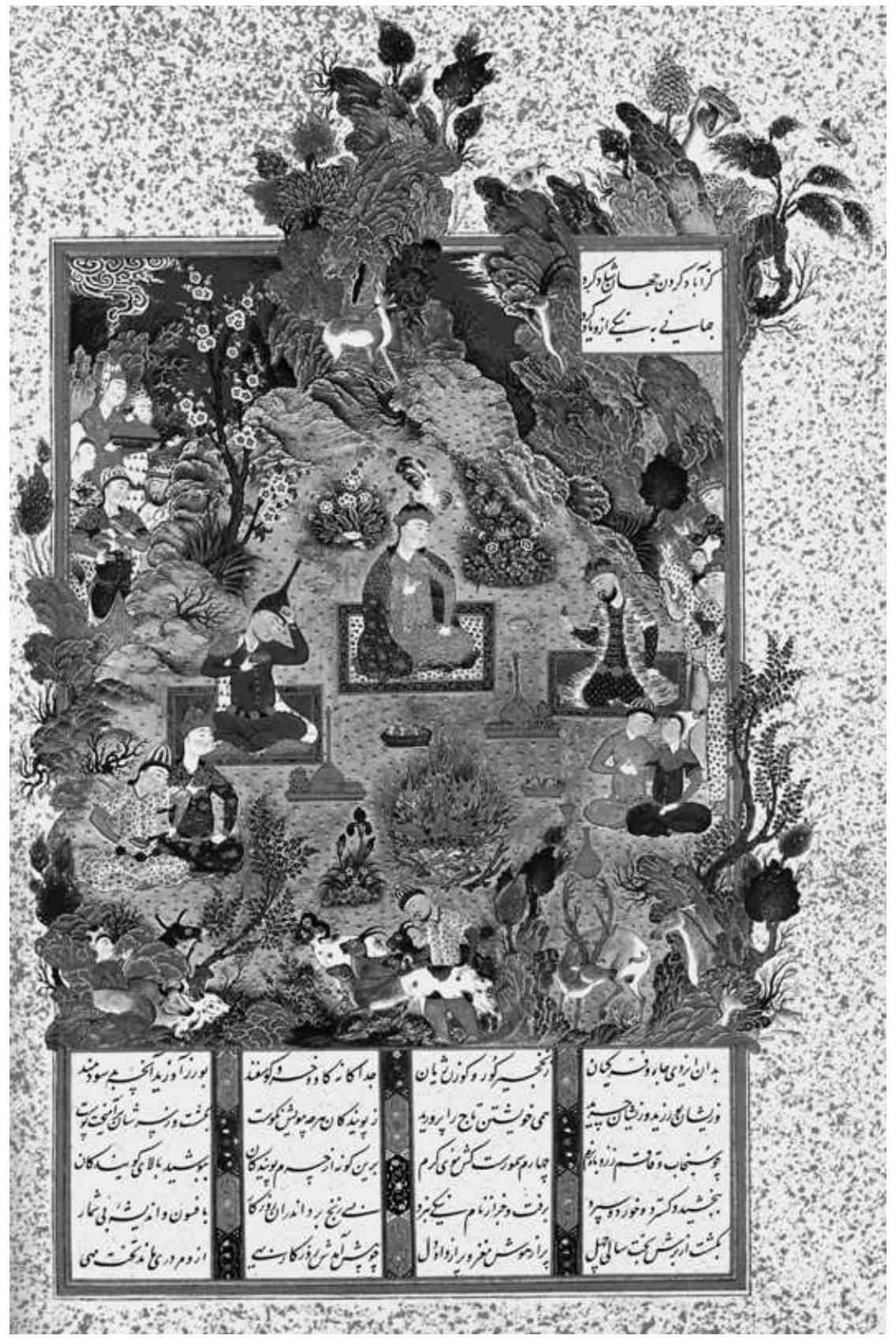

Fig. 2: The Feast of Sada, Shāh Tahmāsb Shāhnāmah, first half of sixteenth century. Metropolitan Museum of Art, 1970.301.2, fol. 22v. 


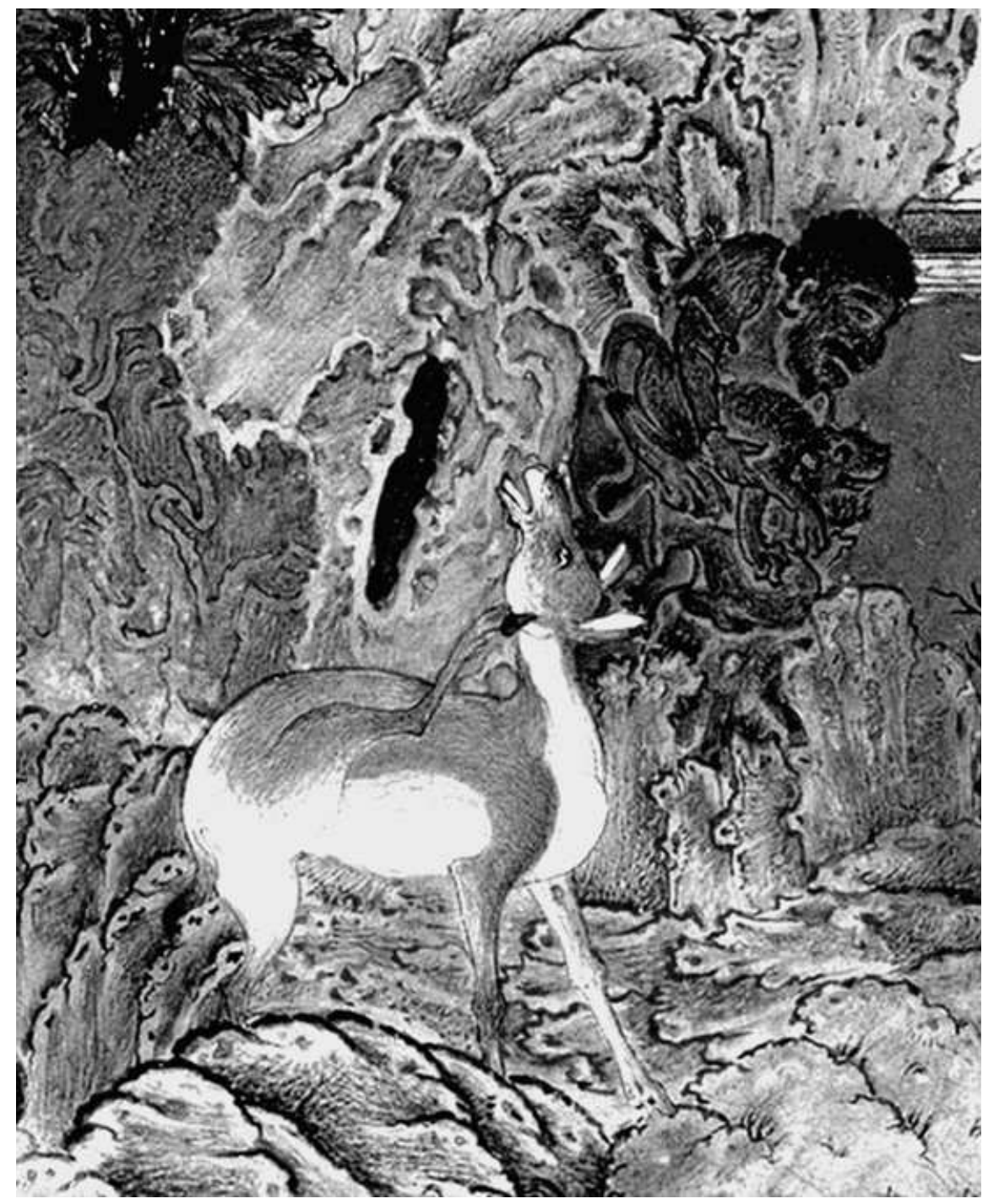

Fig. 2a: Detail of The Feast of Sada, Shāh Tahmāsb Shāhnāmah, first half of sixteenth century. Metropolitan Museum of Art, 1970.301.2, fol. 22v. 


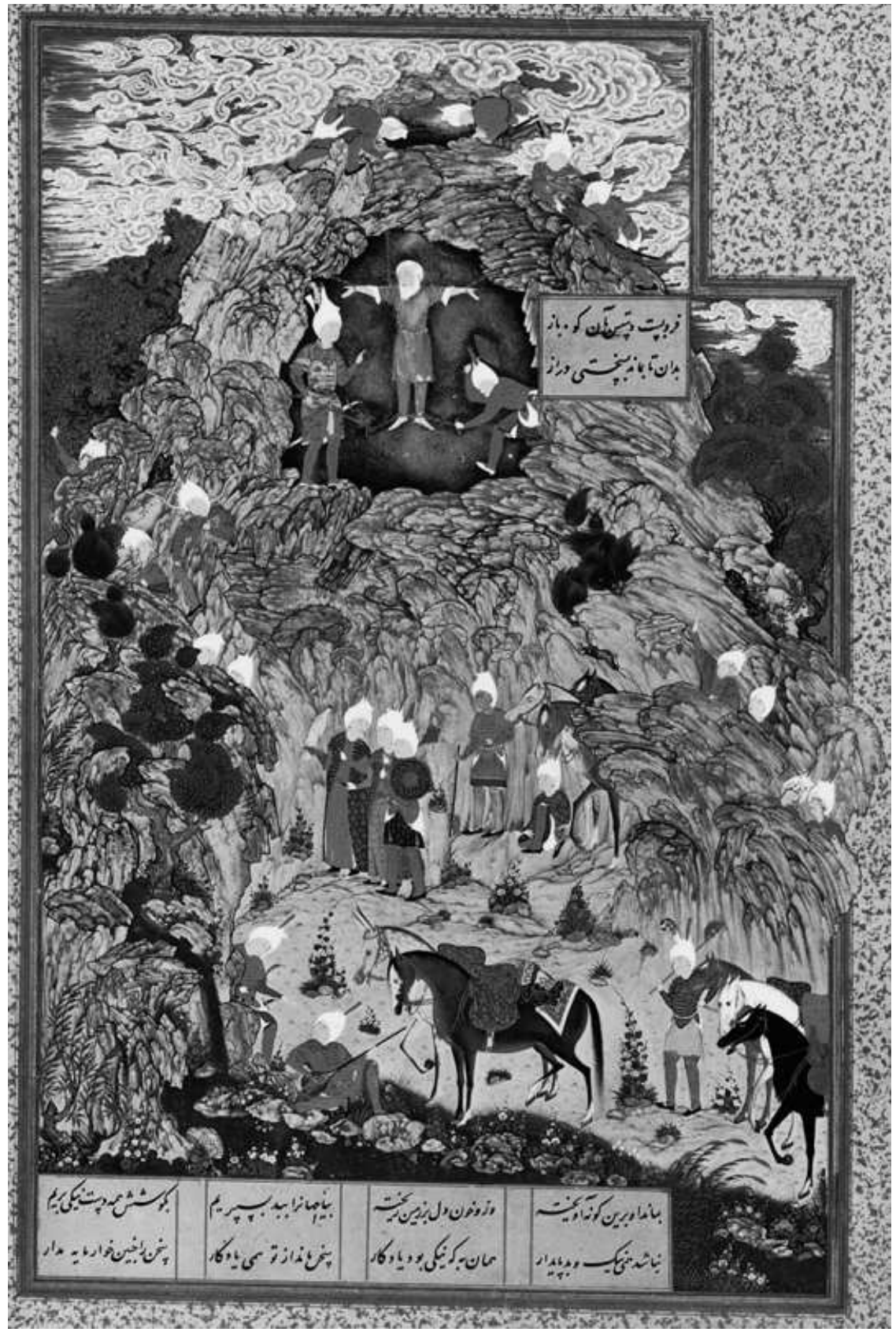

Fig. 3: The Death of Zahhak, Shāh Tahmāsb Shāhnāmah, first half of sixteenth century. Metropolitan Museum of Art, 1970.301.2, fol. 37v. 


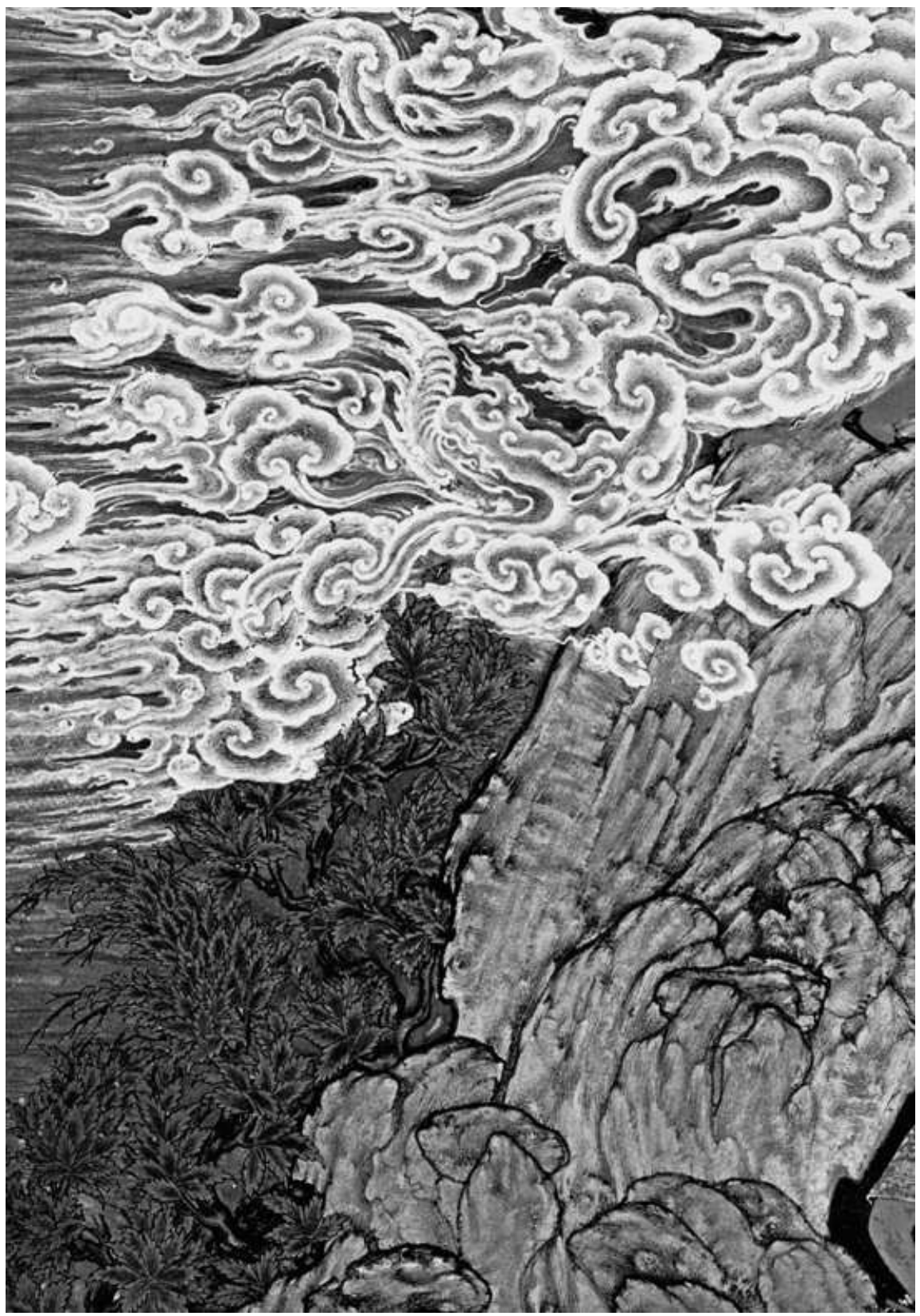

Fig. 3a: Detail of The Death of Zahhak, Shāh Tahmāsb Shāhnāmah, first half of sixteenth century. Metropolitan Museum of Art, 1970.301.2, fol. 37v. 


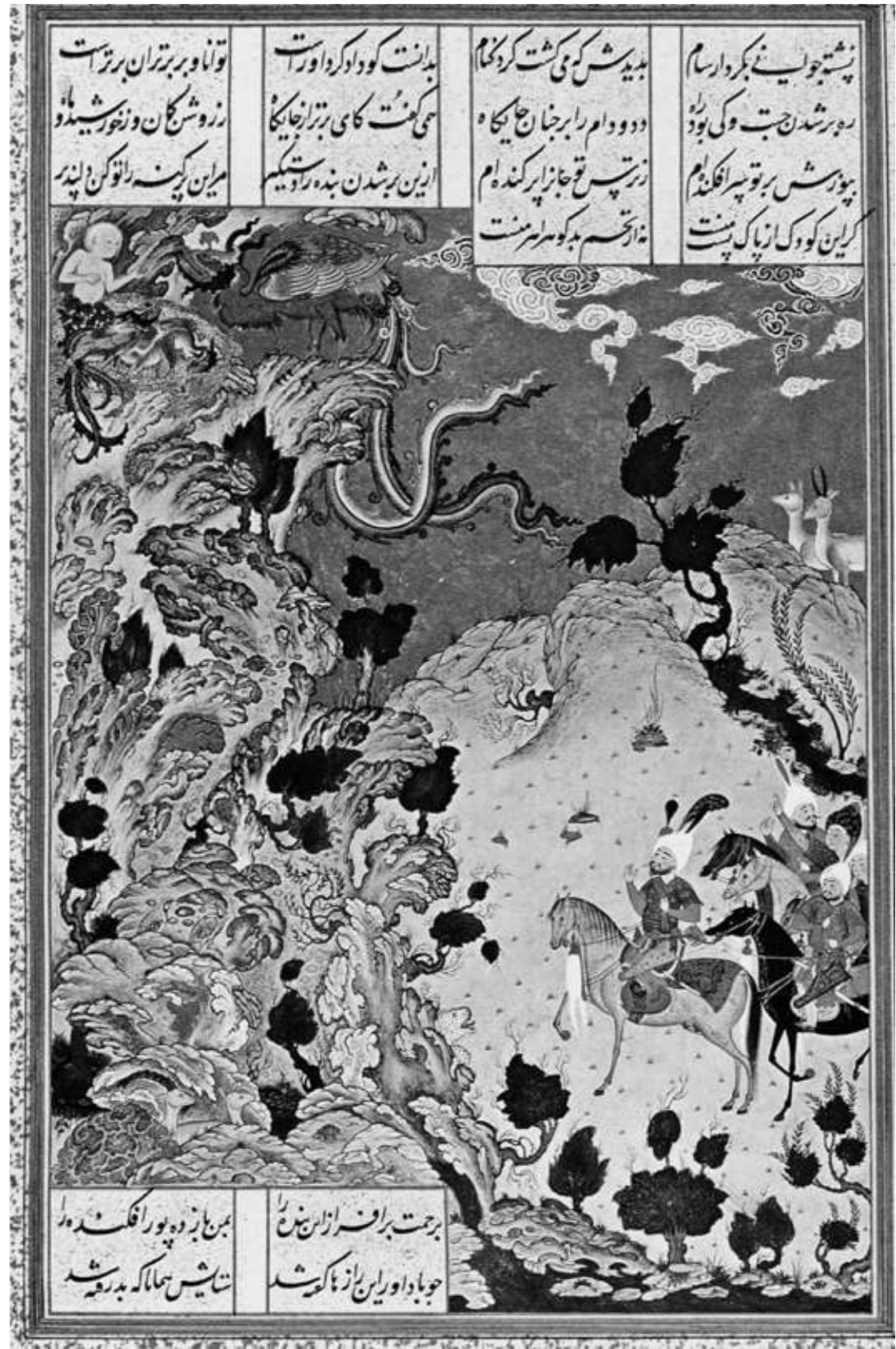

Fig. 4: Zal is Sighted by a Caravan, Shāh Tahmāsb Shāhnāmah, first half of sixteenth century. Metropolitan Museum of Art, 1970.301.2, fol. 63v. 


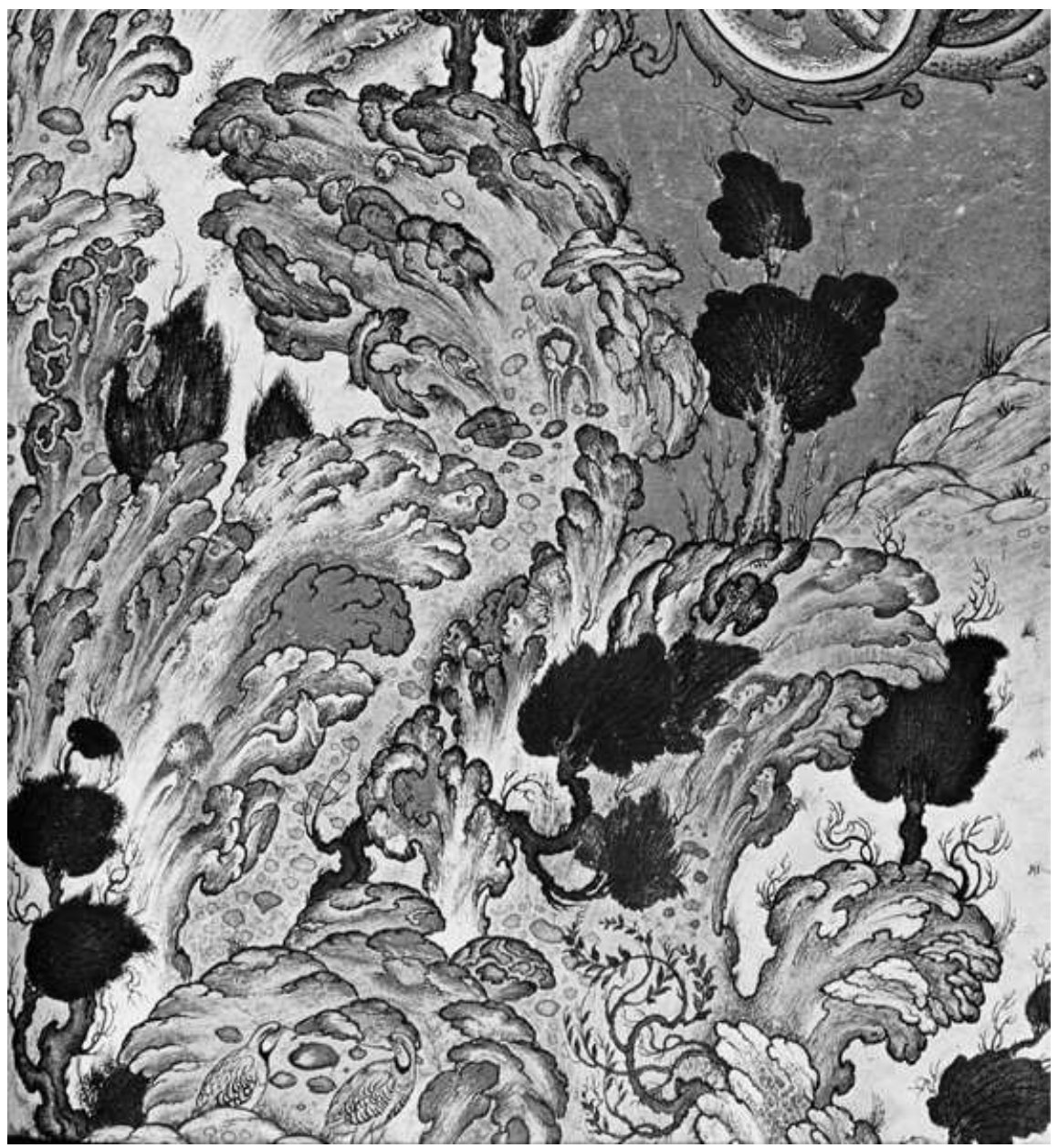

Fig. 4a: Detail of Zal is Sighted by a Caravan, Shāh Tahmāsb Shāhnāmah, first half of sixteenth century. Metropolitan Museum of Art, 1970.301.2, fol. 63v. 


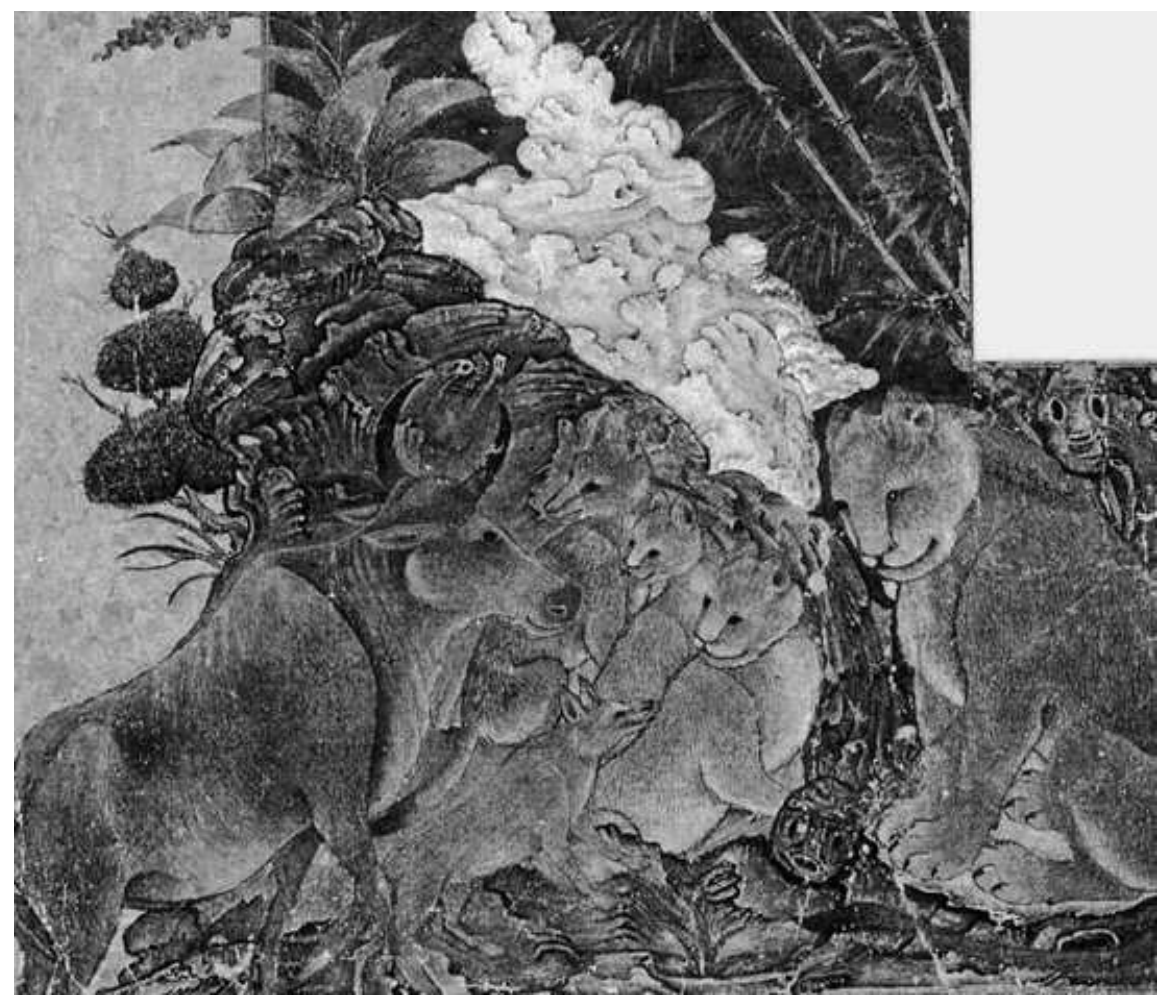

Fig. 5: The Lion-King receives Shanzabah, Kalīla wa Dimnah, circa 1360. Istanbul University Library, F. 1422, fol. 25v. 


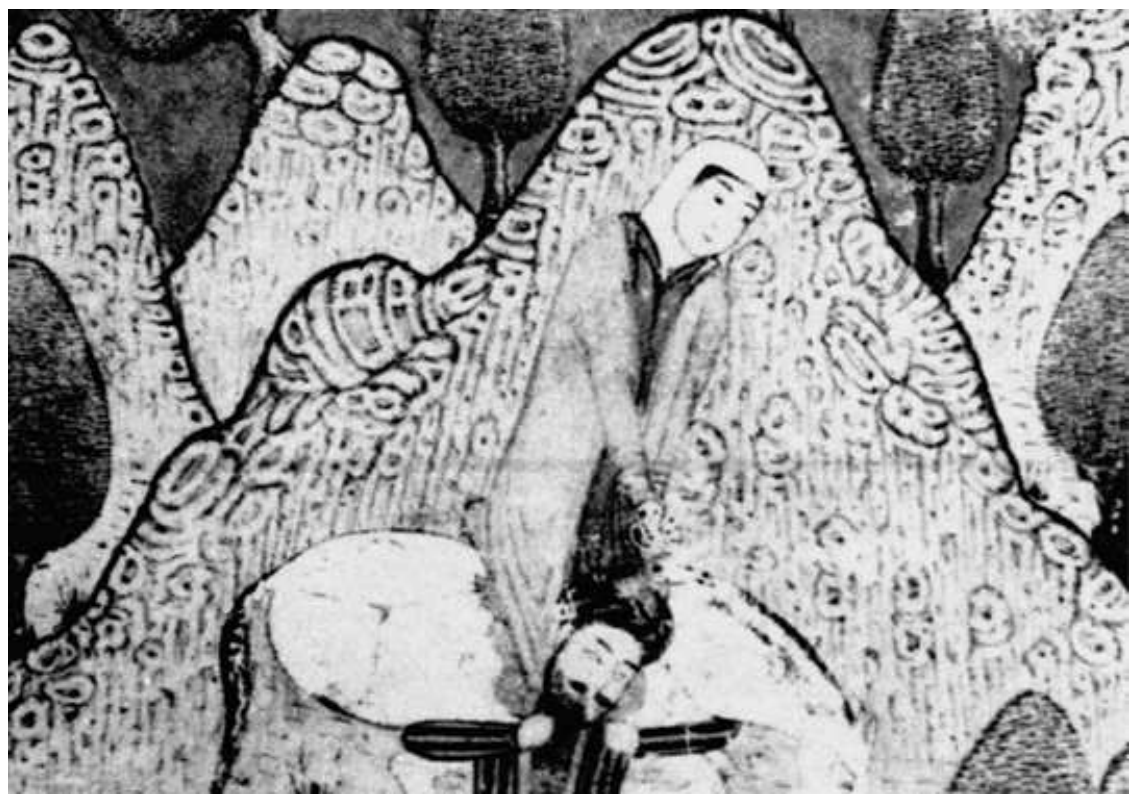

Fig. 6: Farhād Carries Shīrīn, Khamsah of Nizamī, 1439. Uppsala University Library, 0. Vet. 82, fol. $78 \mathrm{v}$.

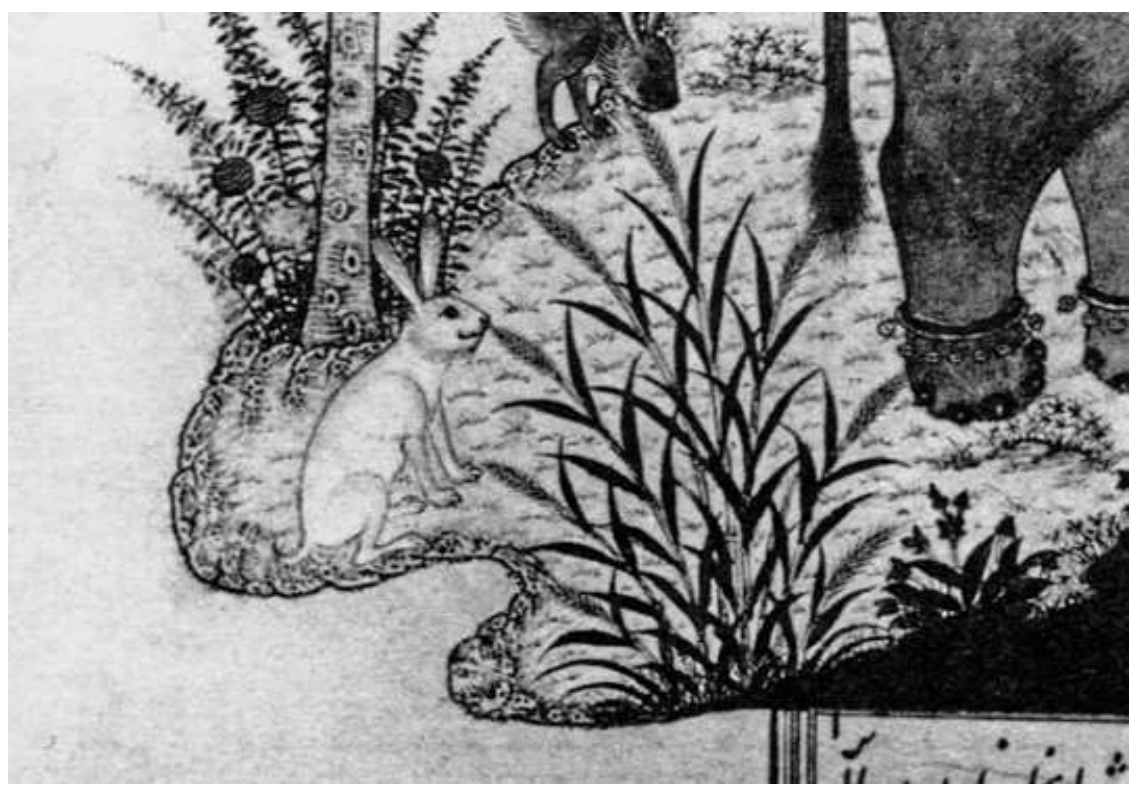

Fig. 7: The Elephants at a Pool, Kalīla wa Dimnah, 1429. Topkapı Palace Library, R. 1022, fol. 77r. 


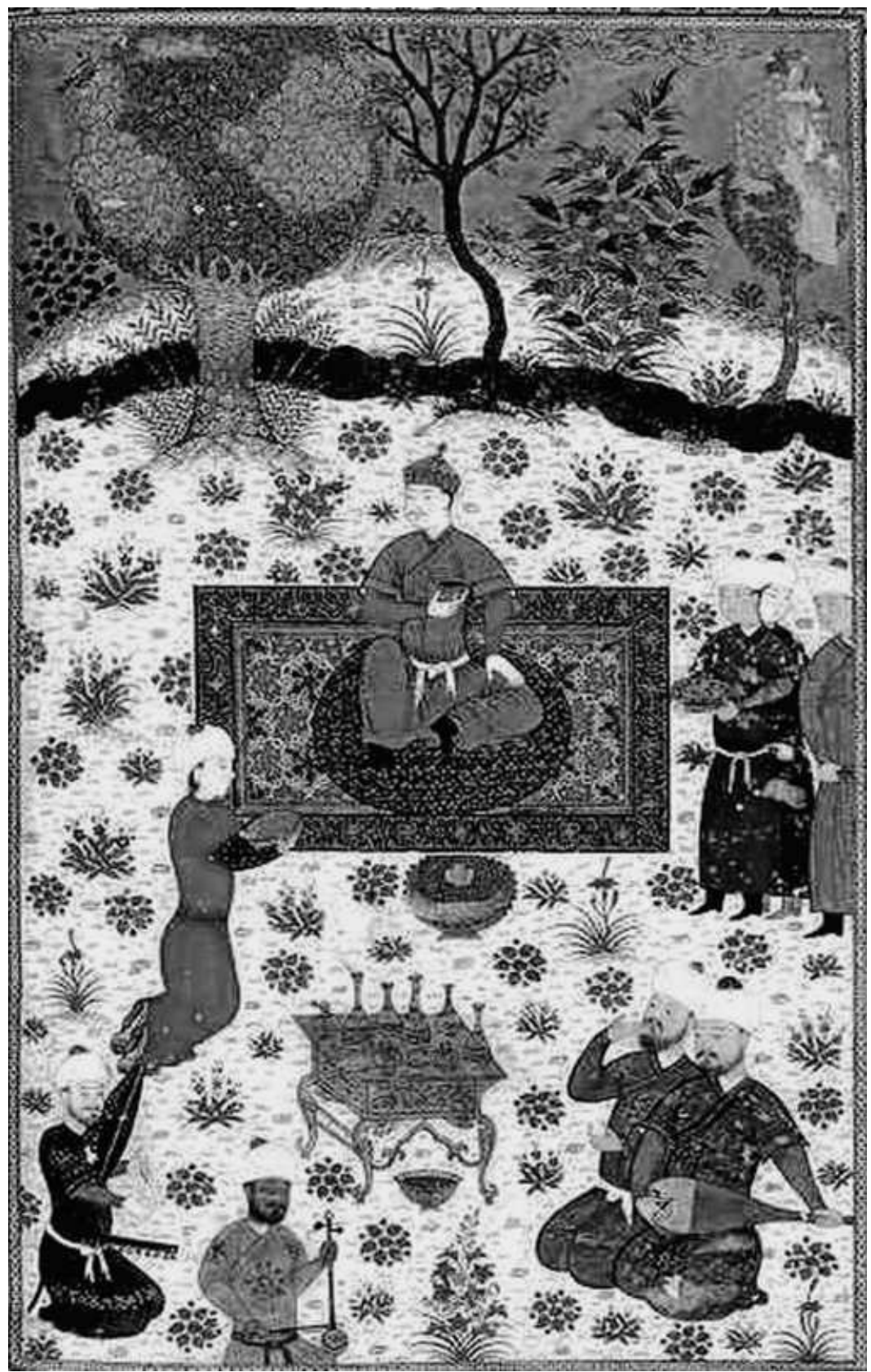

Fig. 8: Bāyșunghur Seated in a Garden, Kalïla wa Dimnah, 1429.

Topkapı Palace Library, R. 1022, fol. $1 v$. 


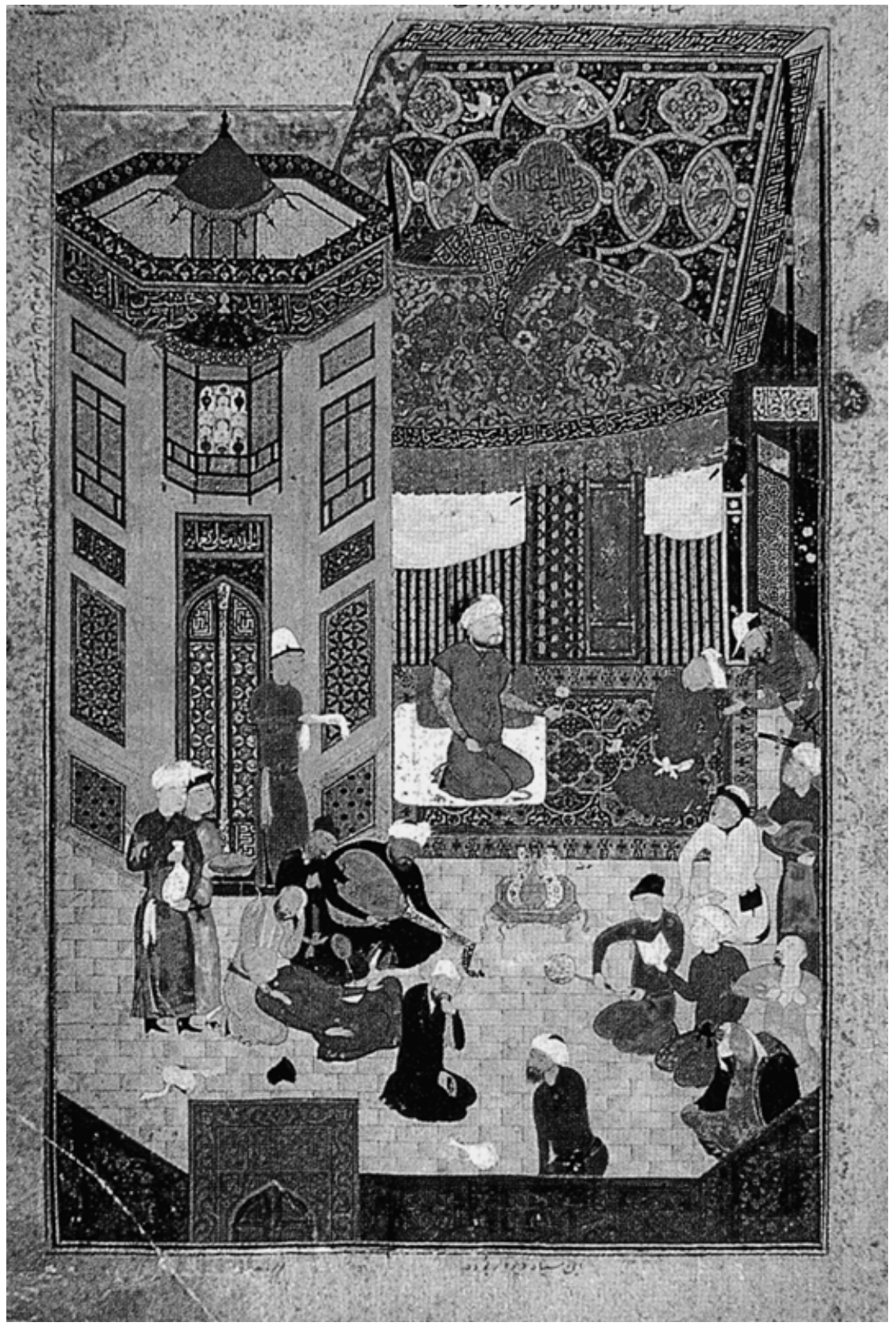

Fig. 9a: Bihzād, A Royal Feast, Būstān of Sa'dī, 1488/1489. National Library, Cairo, adab farsī 908, fol. $1 \mathrm{v}$. 


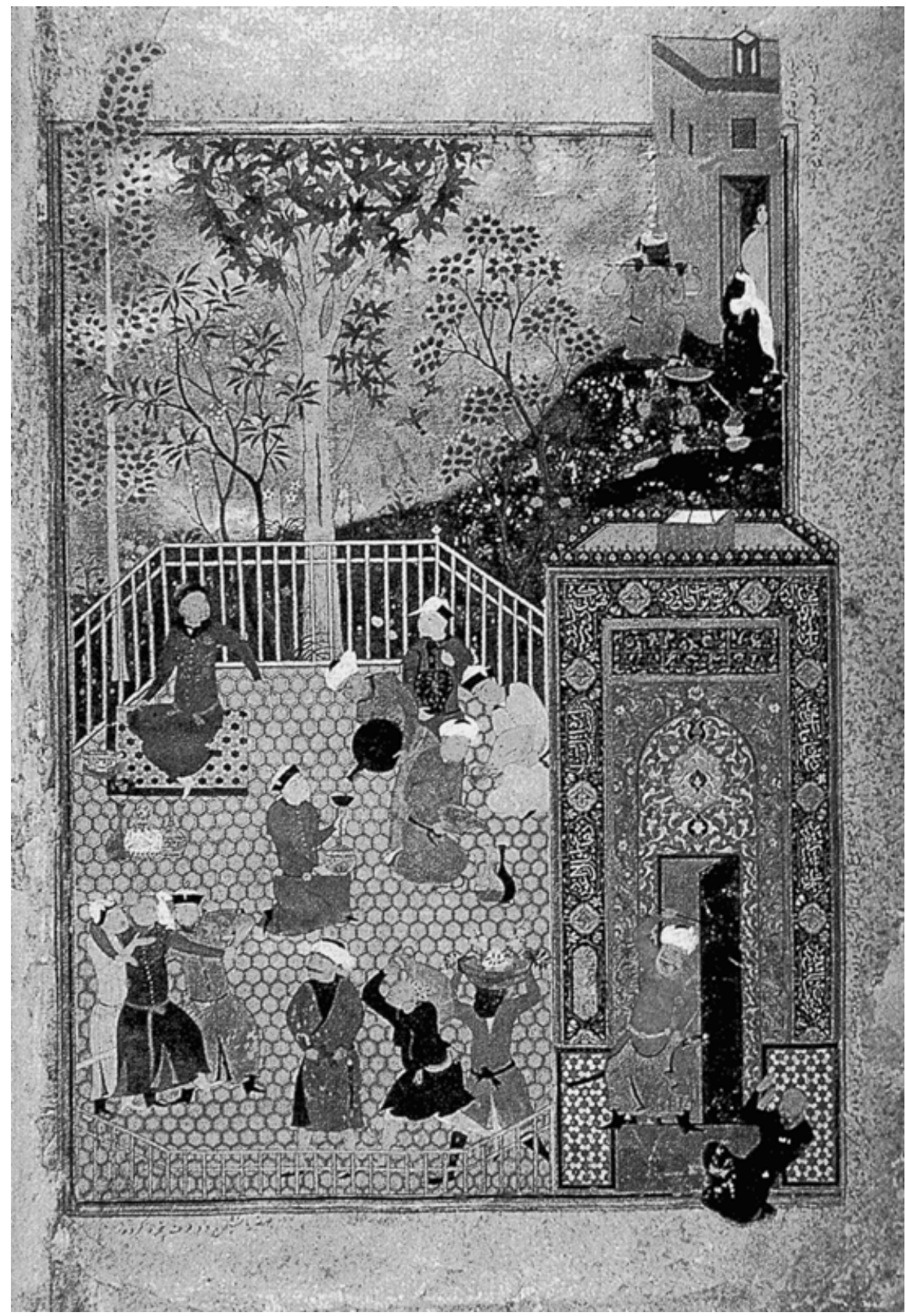

Fig. 9b: Bihzād, A Royal Feast, Būstān of Sa'dī, 1488/89.

National Library, Cairo, adab farsī 908, fol. 2r. 


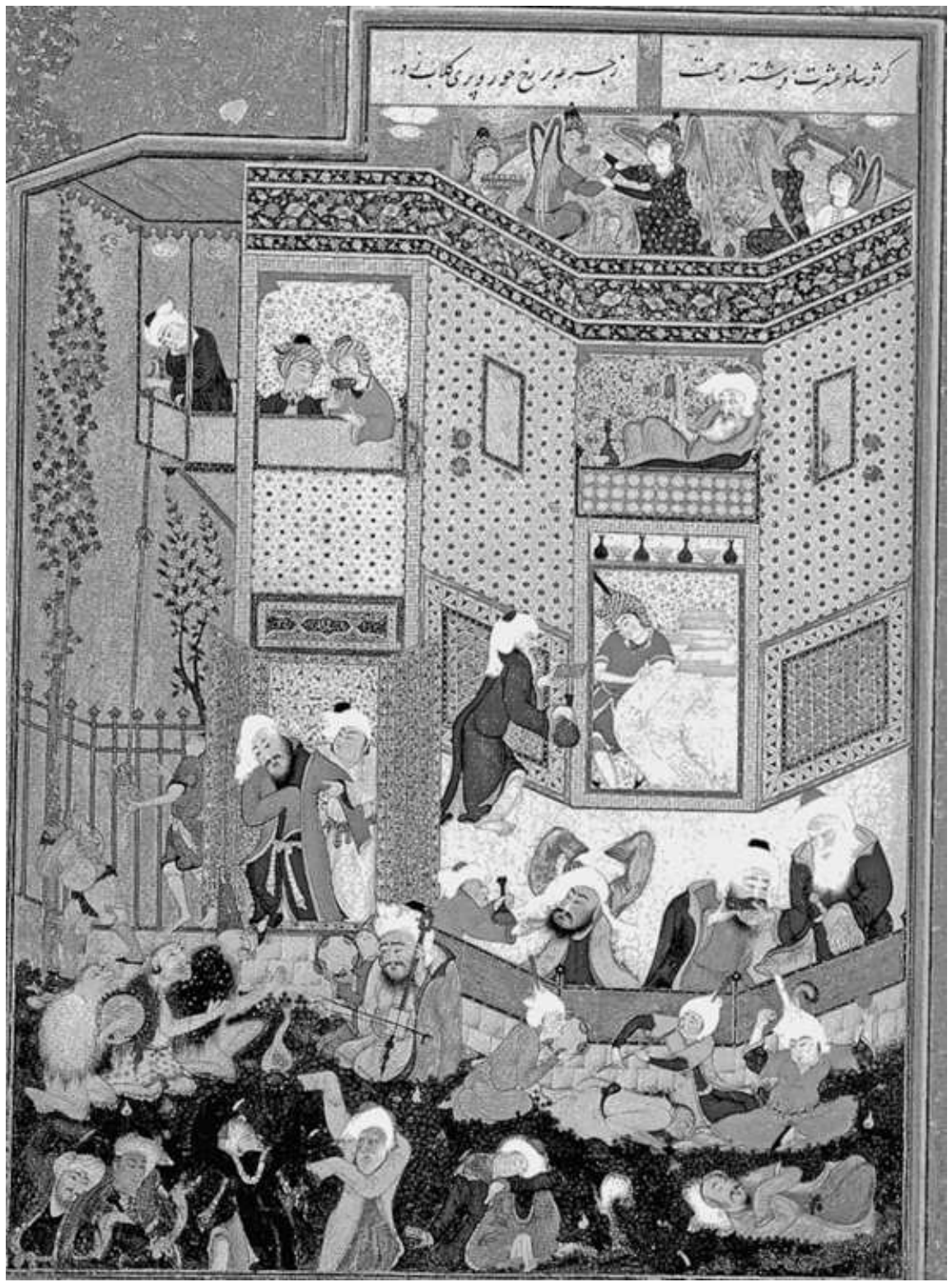

Fig. 10: Sultan Muhammad, Ode to Drunkenness, Divan of Hāafiz, 1527.

Arthur M. Sackler Gallery, 1988.460.3, fol. 135. 


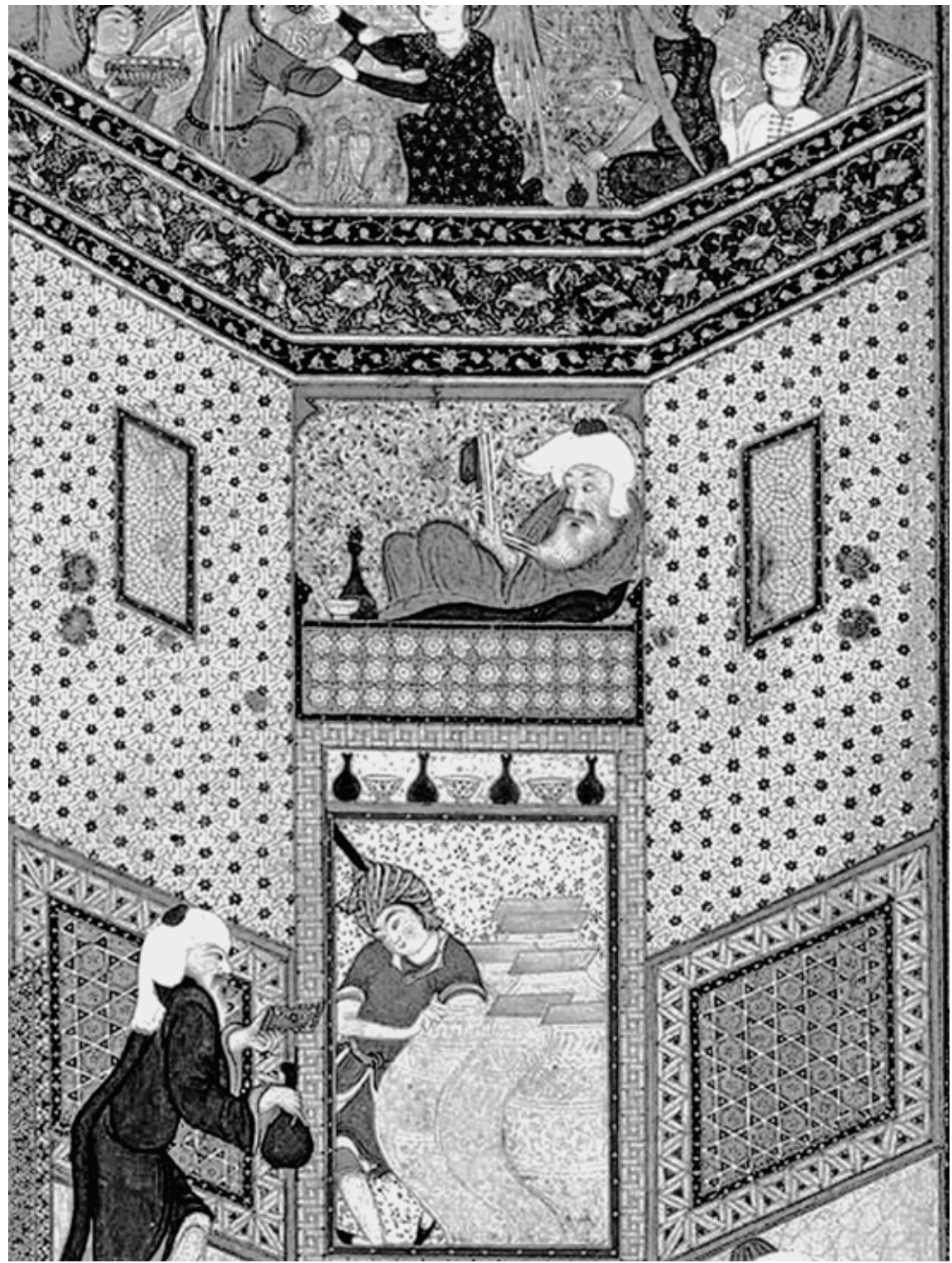

Fig. 10a: Detail of Sultan Muḥammad's Ode to Drunkenness, Divan of Ḥāfiẓ, 1527. Arthur M. Sackler Gallery, 1988.460.3, fol. 135. 


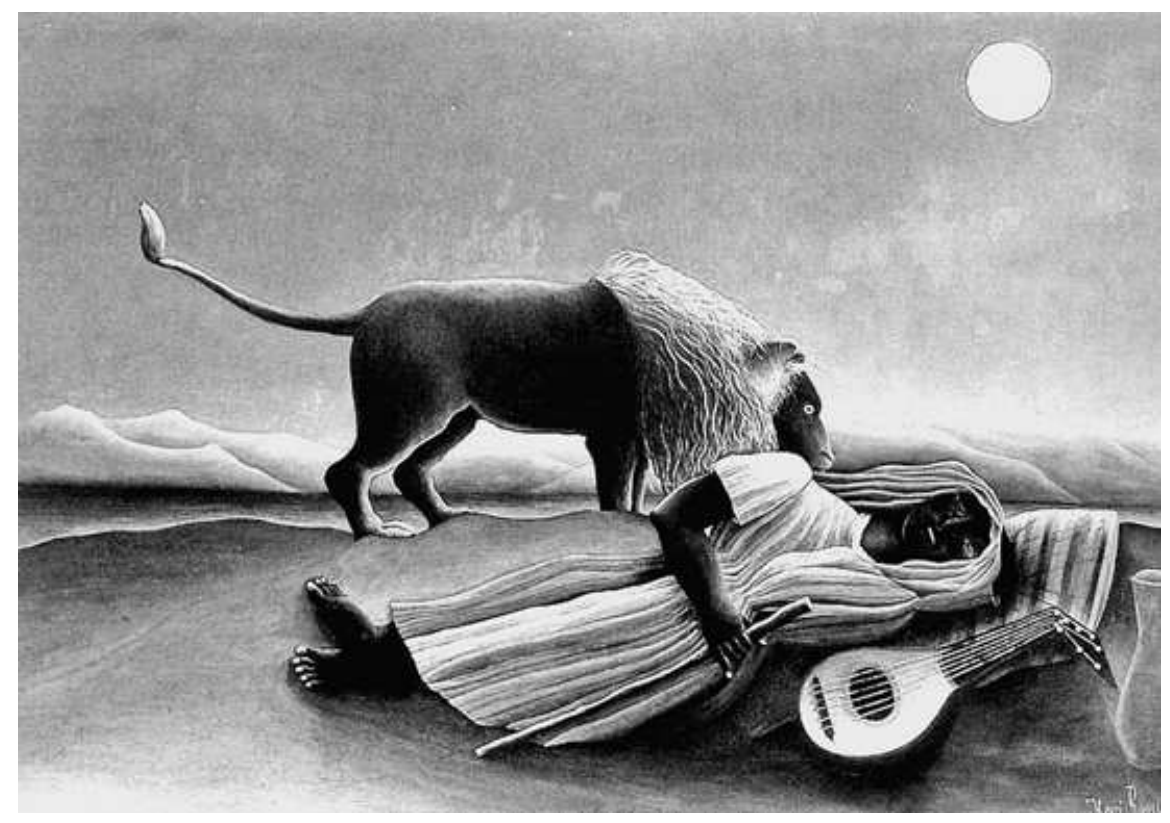

Fig. 11: Henri Rousseau, Sleeping Gypsy, 1897. Museum of Modern Art, 646.1939. 


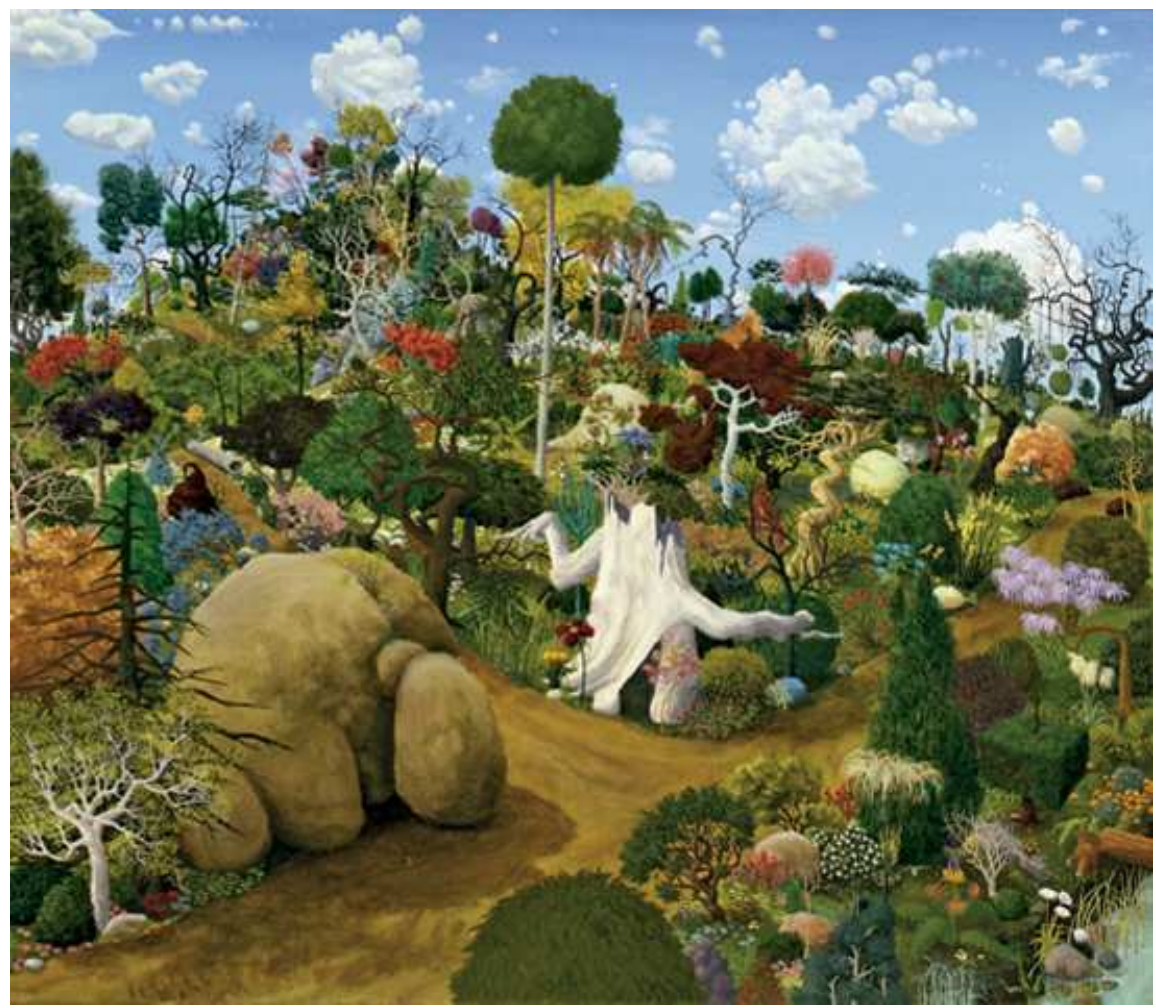

Fig. 12: Gage Taylor, Mescaline Woods, 1969. The Haggin Museum, Stockton, California. 


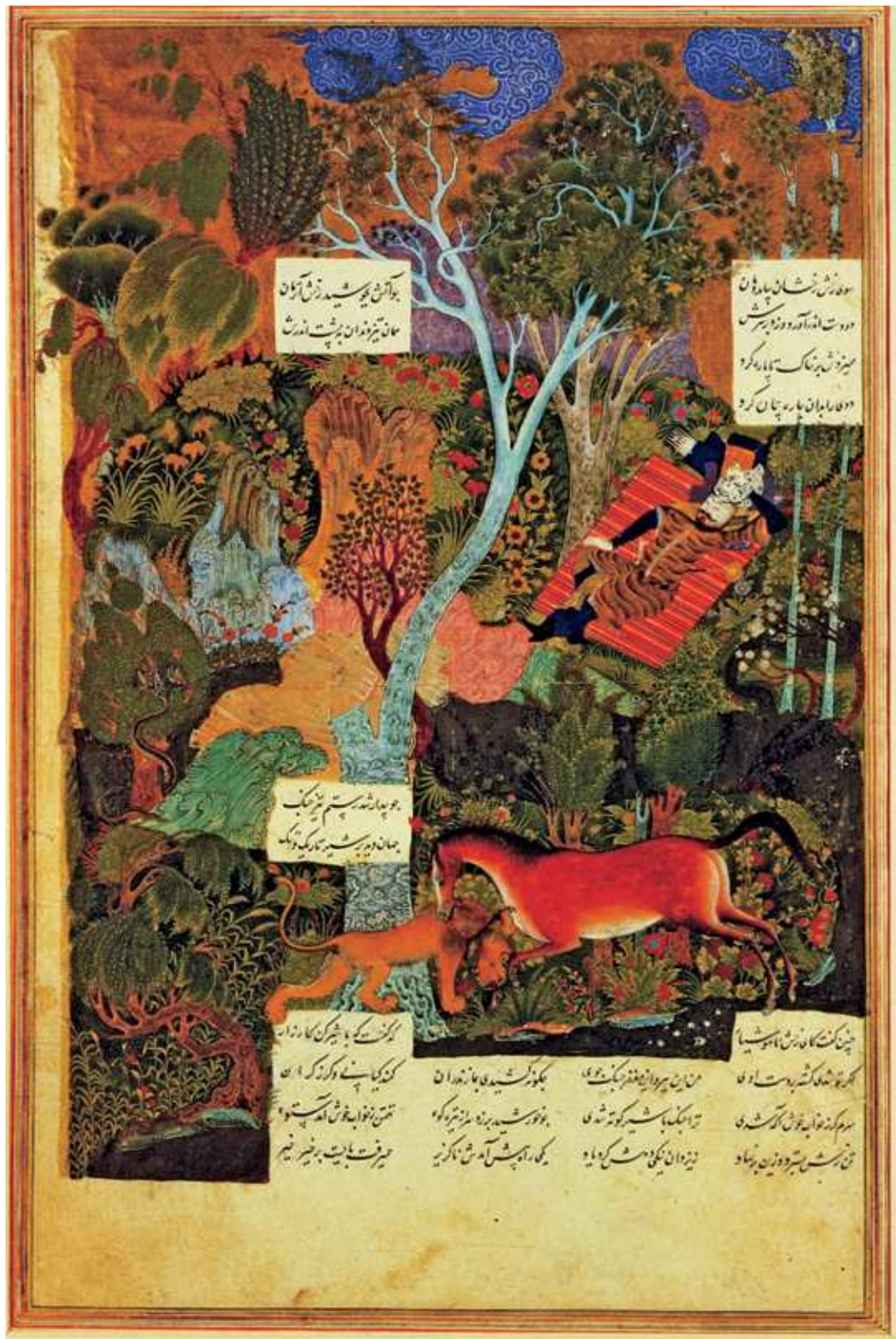

Fig. 13: Rustam Sleeping While Rakhsh Fights the Lion, detached page from an unfinished Shāhnāmah, early sixteenth century. British Museum, 1948,1211,0.23. 


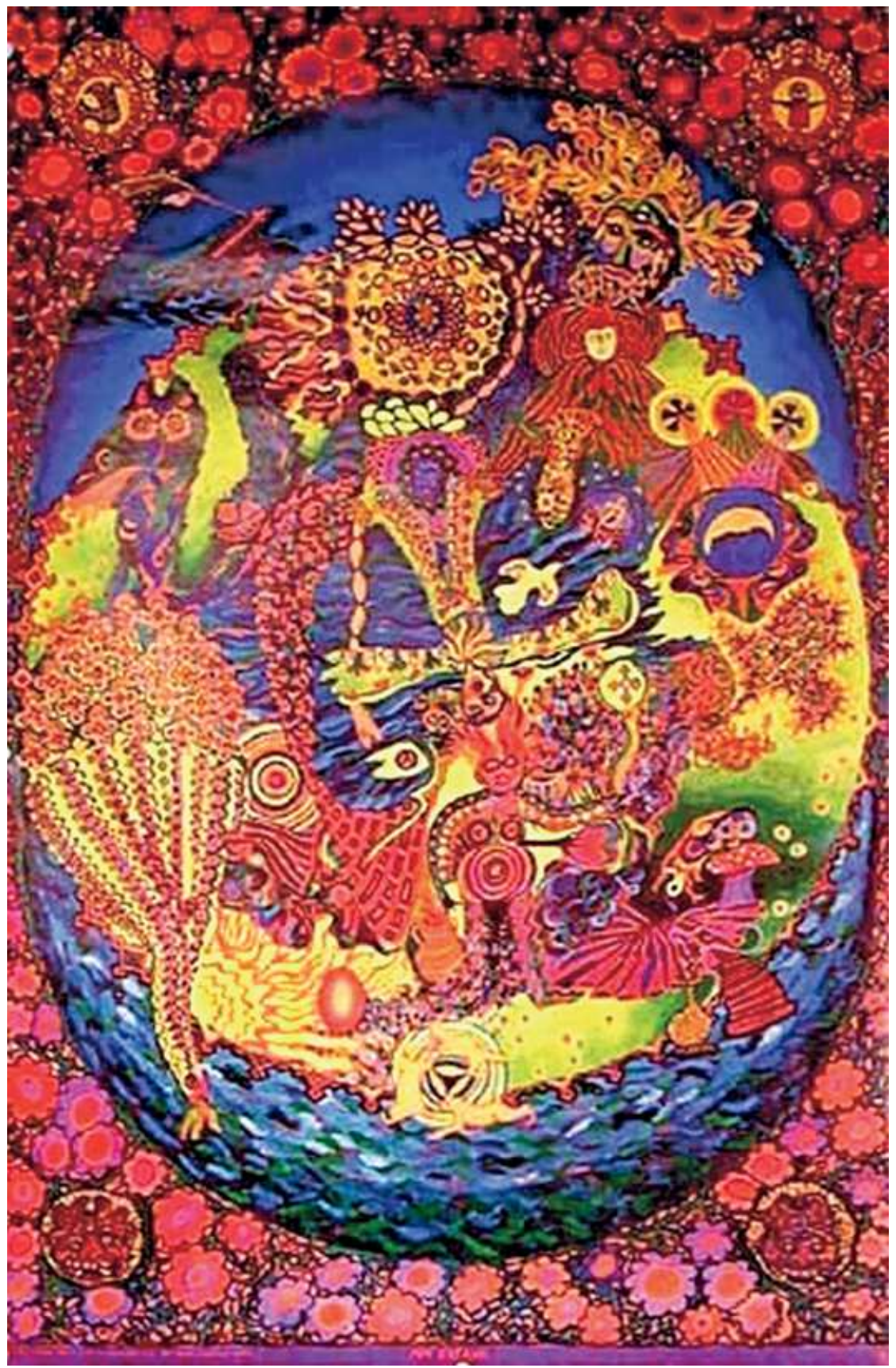

Fig. 14: Irene McHugh, Pipe Dreams, circa 1968. Courtesy of Joseph Mc Hugh. 


\section{Bibliography}

Albright, Th. Art in the San Francisco Bay Area, 1945-1980: An Illustrated History (Berkeley, Los Angeles: University of California Press, 1985).

ATASOY, N. “Illustrations Prepared for Display During Shahname Recitals," in: Fifth International Congress of Iranian Art (Tehran: Ministry of Culture and Arts, 1972), pp. 262-272.

BAHARI, E. Behzad: Master of Persian Painting (London: I.B. Tauris, 1996).

BAXANDall, M. Painting and Experience in Fifteenth-Century Italy (Oxford, New York: Oxford University Press, 1974).

TEN BeRGE, J. "Jekyll and Hyde Revisited: Paradoxes in the Appreciation of Drug Experiences and Their Effects on Creativity," Journal of Psychoactive Drugs 34 (2002), pp. 249-262.

Воотн, M. Opium: A History (New York: St. Martin's Griffin, 1998).

Brend, B. "Rocks in Persian Miniature Painting," in: Landscape Style in Asia, ed. W. WATson (London: SOAS, 1979), pp. 111-137.

BRookshaw, D. "Palaces, Pavilions and Pleasure-Gardens: The Context and Setting of the Medieval Majlis," Middle Eastern Literatures 6 (2003), pp. 199-223.

CANBY, S. The Rebellious Reformer (London: I.B. Tauris, 1996).

CLASSEN, C. Worlds of Sense: Exploring the Senses in History and Across Cultures (London, New York: Routledge, 1993).

Cowen, J. Kalila wa Dimna: An Animal Allegory of the Mongol Court (New York, Oxford: Oxford University Press, 1989).

ERGIN, N. "The Fragance of the Divine: A Group of Ottoman Incense Burners in the Museum of Turkish and Islamic Art, Istanbul, and Their Context," The Art Bulletin 96/1 (forthcoming 2014).

ERgin, N. “Ottoman Royal Women's Spaces: The Acoustic Dimension,” Journal of Women's History 26 (forthcoming 2014).

ERgin, N. "A Multi-Sensorial Message of the Divine and the Personal: Qur'anic Inscriptions and Recitation in Sixteenth-Century Ottoman Mosques," in: Calligraphy in Islamic Architecture: Space, Form, and Function, ed. M. GHARIPOURI and I.C. SCHICK (Edinburgh: Edinburgh University Press, forthcoming 2013).

ERGIN, N. "The Soundscape of Sixteenth-Century Istanbul Mosques: Architecture and Qur'an Recital," Journal of the Society of Architectural Historians 67 (2008), pp. 204-221.

Etting hausen, R. "The Categorization of Persian Painting," in: Studies in Judaism and Islam, ed. S. Morag (Jerusalem: Magnes Press, 1981), pp. 55-63.

FetVACI, E. Viziers to Eunuchs: Transitions in Ottoman Manuscript Patronage, 1566-1617 (PhD diss., Harvard University, 2005).

Golombeк, L. “Toward a Classification of Islamic Painting," in: Islamic Art in the Metropolitan Museum, ed. R. Etting hausen (New York: Metropolitan Museum of Art, 1972), pp. 23-34.

Gonzalez, V. "The Comares Hall in the Alhambra and James Turrell's The Space That Sees:

A Comparison of Aesthetic Phenomenology," Muqarnas 20 (2003), pp. 253-278.

Gosting, N. "Snakes in the Grass," Art \& Artists 4 (1969), p. 26.

Grabar, O. Mostly Miniatures: An Introduction to Persian Painting (Princeton: Princeton University Press, 2000).

Grabar, O. "Persian Miniatures: Illustrations or Paintings," in: The Persian Presence in the Islamic World, ed. R. Hovannisian \& G. SABAGH (Cambridge: Cambridge University Press, 1998), pp. 199-217.

Gruber, Ch. “The Prophet Muhammad's Ascension (Mi'raj) in Islamic Painting and Literature: 
Evidence from Cairo Collections," Bulletin of the American Research Center in Egypt 185 (2004), pp. 24-31.

harman, W., McKim, R., Mogar, R., Fadiman, J. \& Stolaroff, M. "Psychedelic Agents in Creative Problem-Solving: A Pilot Study,” Psychological Reports 19 (1966), pp. 211-227. HAYTER, A. Opium and the Romantic Imagination: Addiction and Creativity in De Quincey, Coleridge, Baudelaire and Others (Wellingborough: Crucible, 1988).

HowES, D. (ed.) Empire of the Senses: The Sensual Culture Reader (Oxford, New York: Berg Publishers, 2005).

Howes, D. Sensual Relations: Engaging the Senses in Culture and Social Theory (Ann Arbor: The University of Michigan Press, 2003).

Howes, D. (ed.) The Varieties of Sensory Experience: A Sourcebook in the Anthropology of the Senses (Toronto: University of Toronto Press, 1991).

JONES, M.T. "The Creativity of Crumb: Research on the Effects of Psychedelic Drugs on the Comic Art of Robert Crumb," Journal of Psychoactive Drugs 39 (2007), pp. 283-291.

KRIPPNER, S. “Psychedelic Drugs and Creativity,” Journal of Psychoactive Drugs 17 (1985), pp. 235-245.

LANGDALE, A. "Aspects of the Critical Reception and Intellectual History of Baxandall's Concept of the Period Eye," Art History 21 (1998), pp. 479-497.

LENTZ, TH.W. "Pictures for the Islamic Book: Persian and Indian Painting in the Vever Collection," Asian Art 1 (1988), pp. 9-35.

LENTZ, TH.W. Painting at Herat under Baysunghur ibn Shahrukh (PhD diss., Harvard University, 1985).

Lentz, Th.W. \& Lowry, G. Timur and the Princely Vision: Persian Art and Culture in the Fifteenth Century (Los Angeles: Los Angeles County Museum, 1989).

MAHIR, B. "A Group of Paintings Used for Picture Recitation," in: Turkish Art: Proceedings of the Tenth International Congress of Turkish Art (Geneva: Fondation Max van Berchem, 1999), pp. 443-456.

MASteRs, R.E.L. \& Houston, J. The Varieties of Psychedelic Experience (New York: Holt, Rinehart and Winston, 1966).

MATtHEE, R. The Pursuit of Pleasure: Drugs and Stimulants in Iranian History, 1500-1900 (Princeton: Princeton University Press, 2005).

Neligan, A.R. The Opium Question, With Special Reference to Persia (London: John Bale Sons \& Danielsson, 1927).

O'Kane, B. "Rock Faces and Rock Figures in Persian Painting," in: Studies in Persian Art and Architecture (Cairo: American University of Cairo Press, 1995), pp. 220-226.

Pedersen, J. The Arabic Book (Princeton: Princeton University Press, 1984).

Pentcheva, B.V. “Hagia Sophia and Multisensory Aesthetics," Gesta 50 (2011), pp. 93-111.

PentcheVA, B.V. The Sensual Icon: Space, Ritual and the Senses in Byzantium (University Park: The Pennsylvania State University Press, 2010).

Pentcheva, B.V. "Moving Eyes: Surface and Shadow in the Byzantine Mixed-Media Relief Icon," Res: Journal of Anthropology and Aesthetics 55/56 (2009), pp. 222-234.

PentcheVA, B.V. “The Performative Icon,” The Art Bulletin 88 (2006), pp. 631-655.

PORTER, Y. Peinture des arts du livre: Essai sur la literature technique indo-persane (Louvain: Peeters, 1992).

DE Quincey, Th. Confessions of an English Opium Eater (London, New York: Penguin, 1986).

RauCH, L. "The Poet Syndrome: Opiates, Psychosis and Creativity," Journal of Psychoactive Drugs 32 (2000), pp. 343-349. 
RoXBURGh, D. Prefacing the Image: The Writing of Art History in Sixteenth-Century Iran (Leiden: Brill, 2001).

Roxburgh, D. "The Study of Painting and the Arts of the Book," Muqarnas 17 (2000), pp. 1-16.

Shanon, B. The Antipodes of the Mind: Charting the Phenomenology of the Ayahuasca Experience (Oxford: Oxford University Press, 2003).

SIMPSON, M.S. “Islamic Painting and History," Asian Art 1 (1988), pp. 3-6.

SIMPSON, M.S. The Illustration of an Epic: The Earliest Shahnama Manuscripts (New York: Garland, 1979).

SмIтн, M.M. Sensory History (Oxford, New York: Berg Publishers, 2007).

SoкоL, D. "Psychedelic Art," The Grove Dictionary of Art, available from http://www.groveart.com.

Soudavar, A. "Between the Safavids and the Mughals: Art and Artists in Transition," Iran 37 (1999), pp. 49-66.

StAHL, P. “Identification of Hallucinatory Themes in the Late Neolithic Art of Hungary," Journal of Psychoactive Drugs 21 (1989), pp. 101-112.

STAHL, P. “The Hallucinogenic Basis of Early Valdivia Phase Ceramic Bowl Iconography," Journal of Psychoactive Drugs 17 (1985), pp. 105-123.

Subtelny, E.M. "Art and Politics in Early Sixteenth Century Central Asia," Central Asiatic Journal 27 (1983), pp. 121-148.

Thackston, W.M. (ed. and transl.) The Baburnama: Memoirs of Babur, Prince and Emperor (New York: The Modern Library, 2002).

Thackston, W.M. (ed. and transl.) A Century of Princes: Sources on Timurid History and Art (Cambridge: Agha Khan Foundation, 1989).

Zayn al-Dīn Wāṣifí, Badā'i' al-wakā'i', ed. A. N. Boldyrev (Moscow: Izdat. Vost. Lit., 1961). 